Prepared in cooperation with the U.S. Fish and Wildlife Service

\title{
Use of Acoustic Backscatter and Vertical Velocity to Estimate Concentration and Dynamics of Suspended Solids in Upper Klamath Lake, South-Central Oregon: Implications for
} Aphanizomenon flos-aquae

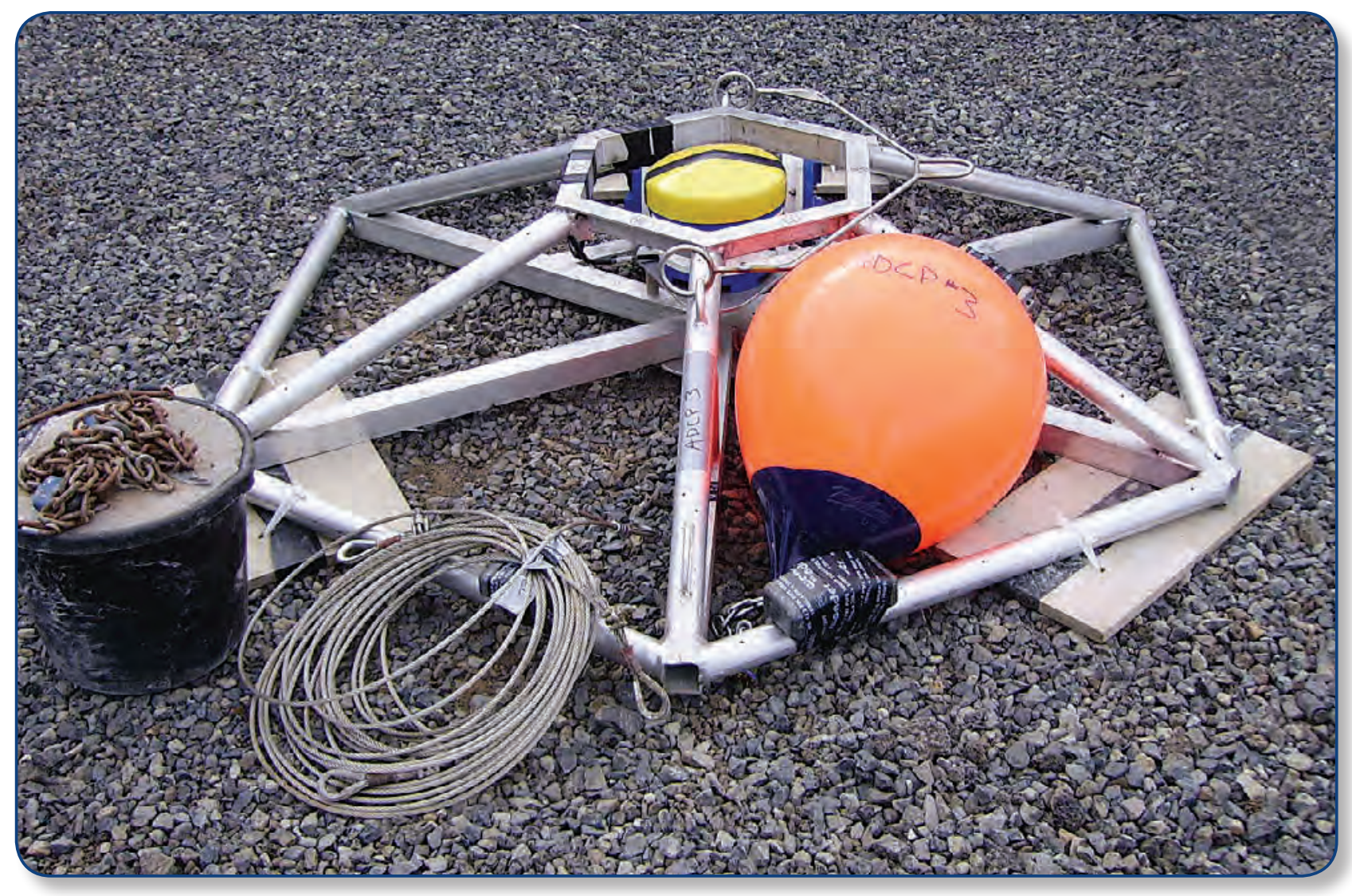

Scientific Investigations Report 2010-5203 
Cover: Acoustic Doppler current profiler (ADCP) with deployment platform prior to being deployed in the Upper Klamath Lake, Oregon, June 2005. (Photograph taken by Roy Wellman, U.S. Geological Survey.) 


\section{Use of Acoustic Backscatter and Vertical Velocity to Estimate Concentration and Dynamics of Suspended Solids in Upper Klamath Lake, South-Central Oregon: Implications for Aphanizomenon flos-aquae}

By Tamara M. Wood and Jeffrey W. Gartner

Prepared in cooperation with the U.S. Fish and Wildlife Service

Scientific Investigations Report 2010-5203 


\section{U.S. Department of the Interior \\ KEN SALAZAR, Secretary \\ U.S. Geological Survey \\ Marcia K. McNutt, Director}

U.S. Geological Survey, Reston, Virginia: 2010

For more information on the USGS - the Federal source for science about the Earth, its natural and living resources, natural hazards, and the environment, visit http://www.usgs.gov or call 1-888-ASK-USGS.

For an overview of USGS information products, including maps, imagery, and publications, visit http://www.usgs.gov/pubprod.

To order this and other USGS information products, visit http://store.usgs.gov.

Any use of trade, product, or firm names is for descriptive purposes only and does not imply endorsement by the U.S. Government.

Although this report is in the public domain, permission must be secured from the individual copyright owners to reproduce any copyrighted materials contained within this report.

Suggested citation:

Wood, T.M., and Gartner, J.W., 2010, Use of acoustic backscatter and vertical velocity to estimate concentration and dynamics of suspended solids in Upper Klamath Lake, south-central Oregon: Implications for Aphanizomenon flosaquae: U.S. Geological Survey Scientific Investigations Report 2010-5203, 20 p. 


\section{Contents}

Abstract
Introduction.
Methods
ADper Klamath Lake Field Sites
Time Series Analyses
Converting ADCP Backscatter to Relative Backscatter and Suspended Solids
Concentrations
Velative Backscatter Intensity
Suspended Solids Concentration
Discussion and Conclusions
Acknowledgments
References Cited

\section{Figures}

Figure 1. Map showing study area and locations of ADCP moorings, meteorological stations, and water quality monitors, Upper Klamath Lake, south-central

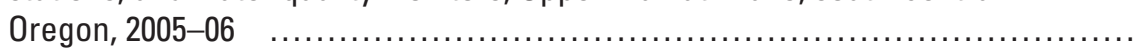

Figure 2. Graph showing diel patterns in the difference between water temperatures measured near-surface and near-bottom at sites MDN, EPT, and MDT in Upper Klamath Lake, south-central Oregon .....................................

Figure 3. Contour plots showing daily variations in relative backscatter and water current speed at the five ADCP deployment sites, Upper Klamath Lake,

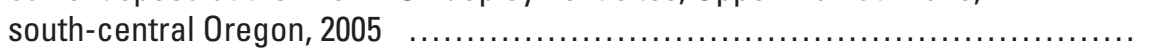

Figure 4. Bar graphs of profiles of correlation between water current speed and relative backscatter at subseasonal time scales, at five sites where ADCPs were deployed, Upper Klamath Lake, south-central Oregon, 2005 ......................

Figure 5. Bar graphs of profiles of correlation between air temperature and relative backscatter at subseasonal time scales, at five sites where ADCPs were deployed, Upper Klamath Lake, south-central Oregon, 2005.

Figure 6. Graphs showing seasonally averaged diel patterns in near-surface vertical velocity at five ADCP sites, Upper Klamath Lake, south-central Oregon, 2005

Figure 7. Graphs showing depth-averaged (computed) suspended solids concentration (SSC) at five ADCP sites and dissolved oxygen at two water quality sites (MDT and MDN), Upper Klamath Lake, Oregon, June 21-September 12, 2005.

Figure 8. Graphs showing A: water temperature at site MDT, $1 \mathrm{~m}$ from surface, and $1 \mathrm{~m}$ from bottom; B: Fraction of total water column mass contained in the upper one-third of the water column, fraction of total water column mass contained in the lower two-thirds of the water column at site ADCP1

Figure 9. Graphs showing seasonally averaged diel pattern of depth-integrated computed suspended solids concentration (SSC) in the entire water column and in the upper and lower one-half (upper one-third and lower two-thirds at ADCP1) of the water column 


\section{Tables}

Table 1. Correlation coefficients between vertical velocities and horizontal currents and air temperature, Upper Klamath Lake, south-central Oregon....

Table 2. Correlations of computed suspended solids concentrations (SSC) at ADCP sites with chlorophyll a and dissolved oxygen at water quality sites, Upper Klamath Lake, south-central Oregon

Table 3. Average mass and average daily range in mass of suspended solids at ADCP sites, Upper Klamath Lake, south-central Oregon

Table 4. Correlation coefficients between the depth-integrated computed suspended solids concentrations (SSC) at ADCP sites and depth-integrated horizontal currents at the same site, or air temperature as measured at site WMR-MET,

Upper Klamath Lake, south-central Oregon 14

\section{Conversion Factors and Datums}

\section{Conversion Factors}

\begin{tabular}{lll}
\hline \multicolumn{1}{c}{ Multiply } & \multicolumn{1}{c}{ By } & \multicolumn{1}{c}{ To obtain } \\
\hline centimeter $(\mathrm{cm})$ & 0.3937 & inch (in.) \\
millimeter $(\mathrm{mm})$ & 0.03937 & inch (in.) \\
meter $(\mathrm{m})$ & 3.281 & foot $(\mathrm{ft})$ \\
kilometer $(\mathrm{km})$ & 0.6214 & mile (mi) \\
square meter $\left(\mathrm{m}^{2}\right)$ & 0.0002471 & acre \\
square meter $\left(\mathrm{m}^{2}\right)$ & 10.76 & square foot $\left(\mathrm{ft}^{2}\right)$ \\
square kilometer $\left(\mathrm{km}^{2}\right)$ & 0.3861 & square mile $\left(\mathrm{mi}^{2}\right)$ \\
meter per second $(\mathrm{m} / \mathrm{s})$ & 3.281 & foot per second $(\mathrm{ft} / \mathrm{s})$ \\
centimeter per second $(\mathrm{cm} / \mathrm{s})$ & 0.328 & foot per second $(\mathrm{ft} / \mathrm{s})$ \\
milligram per liter $(\mathrm{mg} / \mathrm{L})$ & 1.0 & part per million $(\mathrm{ppm})$ \\
micrometer $(\mu \mathrm{m})$ & $3.937 \times 10-5$ & inch (in) \\
cubic micrometer $\left(\mu \mathrm{m}^{3}\right)$ & 61.023 & cubic inch $\left(\mathrm{in}^{3}\right)$ \\
\hline
\end{tabular}

Temperature in degrees Celsius $\left({ }^{\circ} \mathrm{C}\right)$ may be converted to degrees Fahrenheit $\left({ }^{\circ} \mathrm{F}\right)$ as follows:

$$
{ }^{\circ} \mathrm{F}=\left(1.8 x^{\circ} \mathrm{C}\right)+32 \text {. }
$$

Concentrations of chemical constituents in water are given either in milligrams per liter (mg/L) or micrograms per liter $(\mu \mathrm{g} / \mathrm{L})$.

Datums

Vertical coordinate information is referenced to the Upper Klamath Lake Vertical Datum (UKLVD), which is used by the Bureau of Reclamation for reporting the elevation of Upper Klamath Lake.

Horizontal coordinate information is referenced to the North American Datum of 1927 (NAD 27). Elevation, as in this report, refers to distance above the vertical datum. 


\title{
Use of Acoustic Backscatter and Vertical Velocity to Estimate Concentration and Dynamics of Suspended Solids in Upper Klamath Lake, South-Central Oregon: Implications for Aphanizomenon flos-aquae
}

\author{
By Tamara M. Wood and Jeffrey W. Gartner
}

\section{Abstract}

Vertical velocity and acoustic backscatter measurements by acoustic Doppler current profilers were used to determine seasonal, subseasonal (days to weeks), and diel variation in suspended solids in a freshwater lake where massive cyanobacterial blooms occur annually. During the growing season, the suspended material in the lake is dominated by the buoyancy-regulating cyanobacteria, Aphanizomenon flos-aquae. Measured variables (water velocity, relative backscatter $[R B]$, wind speed, and air and water temperatures) were averaged over the deployment season at each sample time of day to determine average diel cycles. Phase shifts between diel cycles in $R B$ and diel cycles in wind speed, vertical water temperature differences $\left(\Delta T^{\circ}\right)$, and horizontal current speeds were found by determining the lead or lag that maximized the linear correlation between the respective diel cycles. Diel cycles in $R B$ were more in phase with $\Delta T^{\circ}$ cycles, and, to a lesser extent, wind cycles, than to water current cycles but were out of phase with the cycle that would be expected if the vertical movement of buoyant cyanobacteria colonies was controlled primarily by light. Clear evidence of a diel cycle in vertical velocity was found only at the two deepest sites in the lake. Cycles of vertical velocity, where present, were out of phase with expected vertical motion of cyanobacterial colonies based on the theoretical cycle for light-driven vertical movement. This suggests that water column stability and turbulence were more important factors in controlling vertical distribution of colonies than light. Variations at subseasonal time scales were determined by filtering data to pass periods between 1.2 and 15 days. At subseasonal time scales, correlations between $R B$ and currents or air temperature were consistent with increased concentration of cyanobacterial colonies near the surface when water column stability increased (higher air temperatures or weaker currents) and dispersal of colonies throughout the water column when the water column mixed more easily. $R B$ was used to estimate suspended solids concentrations (SSC). Correlations of depth-integrated SSC with currents or air temperatures suggest that depthintegrated water column mass decreased under conditions of greater water column stability and weaker currents. Results suggest that the use of measured vertical velocity and acoustic backscatter as a surrogate for suspended material has the potential to contribute significant additional insight into dynamics of Aphanizomenon flos-aquae colonies in Upper Klamath Lake, south-central Oregon.

\section{Introduction}

Upper Klamath Lake, the largest freshwater lake in the State, is located east of the Cascade Range in south-central Oregon. The lake has been historically eutrophic (Eilers and others, 2004) and has experienced annual occurrences of large cyanobacterial blooms (primarily Aphanizomenon flos-aquae, or AFA) in recent decades. Growth and decomposition of dense AFA blooms frequently cause extreme water quality conditions characterized by high $\mathrm{pH}(9-10.2)$ and ammonia concentrations ( $>0.5 \mathrm{mg} / \mathrm{L}$ unionized) and widely variable dissolved oxygen (anoxic to supersaturated) (Wood and others, 2006; Hoilman and others, 2008). These conditions are detrimental to the survival of two endangered fish species endemic to the lake, the Lost River and shortnose suckers. In order to complement water quality samples with better spatial and temporal resolution, it may be possible to use measured acoustic backscatter as a surrogate for suspended solids. In addition, if properly calibrated, acoustic Doppler current profilers (ADCPs) can provide non-intrusive measurements to compute time series of suspended solids concentration (SSC) profiles concurrent with measurements of three-dimensional velocity profiles (Gray and Gartner, 2009). 
Attempts to characterize suspended material from acoustic backscatter, a byproduct of ADCP velocity measurements, have increased as the use of ADCPs has become more widespread. Early studies used ADCP velocity and backscatter measurements to provide qualitative estimates of zooplankton biomass and diurnal patterns of vertical migration (Schott and Johns, 1987; Flagg and Smith, 1989; Heywood and others, 1991; Zhou and others, 1994), and even defined multiple diel migration layers (Plueddemann and Pinkel, 1989; Heywood, 1996; Pinot and Jansa, 2001; Ashjian and others, 2002; Sutor and others, 2005). Whereas most of these studies used relatively low frequency ADCPs (most often $150 \mathrm{kHz}$ ) in deep waters, Lorke and others (2004) applied acoustic backscatter from a $600 \mathrm{kHz}$ ADCP to quantify distribution and movement of zooplankton, primarily Chaoborus flavicans, populations in lakes ( $<50 \mathrm{~m}$ depth). Lorke and others (2004) found very good correlation between backscatter estimates and measured concentrations and a strong correlation between up and down migration and times of sunset and sunrise.

Others have attempted to quantify the concentration of suspended solids that primarily are inorganic material through laboratory or field calibrations. Laboratory experiments designed to calibrate backscatter to SSC were conducted by Thorne and others (1991) and Lohrmann and Huhta (1994). Thevenot and others (1992) developed calibration parameters for reliable estimates of SSC as part of a study to monitor dredged material using Broadband-ADCPs (2.4 MHz and $600 \mathrm{kHz}$ ). Thevenot and others (1992), Thevenot and Kraus (1993), and Holdaway and others (1999) found concentration estimates from calibrated backscatter were comparable or superior to estimates from transmissometers. Gartner (2004) computed SSC using 1.2- and 2.4-MHz ADCPs. Results compared favorably to those computed from optical backscatter sensors (OBS) (within about 10 percent of the range of OBS estimates and within about 40 percent of the mean of OBS estimates over a 7-day time series). Wall and others (2006) used ADCP backscatter to compute suspended sediment discharge. Regression of measured to computed SSC values resulted in an $R^{2}$ of 0.86 and a standard deviation of $7.9 \mathrm{mg} / \mathrm{L}$ over a range of about 5-75 mg/L. Finally, Topping and others (2007) applied a multi-instrument, multi-frequency approach; they related acoustic attenuation to concentration of suspended silt and clay and acoustic backscatter to concentration of suspended sand. Computed values were within 5 percent of those measured by conventional methods.

Examples of the application of ADCP backscatter measurements to the study of phytoplankton are scarce in the literature and typically provide descriptions of the spatial distribution of phytoplankton rather than predictions of phytoplankton biomass. The paucity of studies relating ADCP backscatter to phytoplankton may be a result of a limitation of the acoustic backscatter technique - the relation between particle size and acoustic frequency. Errors in estimates occur when the size of suspended material is too small or too large for the acoustic frequency being used.
Individual AFA cells typically are small (about 100$130 \mu^{3}$ ) (Konopka and others, 1987) and are often grouped in filaments ranging from 8 to 50 cells (Huisman and others, 1999). Thus filament volumes might range from about 800 to $6,500 \mu^{3}$ (equivalent radii about 5-12 $\mu \mathrm{m}$ ). However, the AFA is found in flakes consisting of thousands of filaments and the number of flakes may exceed thousands per liter at the height of the bloom (Geiger and others, 2004). Thus, AFA flakes have a range of equivalent radii from about 50 to $250 \mu \mathrm{m}$. These particles far outnumber other scatterers in the lake and are well within the size range suitable for the frequency of ADCPs used in Upper Klamath Lake that are described here.

This paper describes a study to determine if relative backscatter, $R B$ (acoustic backscatter corrected for transmission losses from acoustic beam spreading and attenuation in units of $\mathrm{dB}$ ) and vertical velocity measurements by ADCPs can be used to better understand seasonal, subseasonal, and diel dynamics of cyanobacterial colonies (AFA) in a shallow freshwater lake. Here, the term seasonal refers to variations or trends that occur over time scales consistent with the ADCP deployment length (about $85-125$ days). The term subseasonal is used to define variations or trends that have time scales greater than diel but less than seasonal, that is, time scales of days to weeks corresponding to weather patterns. The $R B$ and vertical velocity data measured by ADCPs in Upper Klamath Lake were used to establish the typical diel cycles of mass distribution and movement through the water column, and how these cycles relate to the typical diel cycles in thermal stratification, mixing, and light availability. The theoretical model of light-driven vertical migration of buoyant cyanobacteria is based on the fact that density of cells changes during the day in response to availability of light and nutrients. When light is available in excess of growth capacity, cells become negatively buoyant by limiting the production of gas vesicles or by increasing carbohydrate production, thus gaining ballast. If nutrients are plentiful and cells are light-limited, cells become positively buoyant by consuming carbohydrate ballast or increasing the synthesis of gas vesicles. As a result, theoretically, if movement is light-driven then the cells of buoyant cyanobacteria generally rise in the water column during evening and early morning (during darkness) and sink in the water column during morning and afternoon (during daylight) (Konopka and others, 1987; Porat and others, 2001). Like the AFA dynamics, the external forcings that determine stratification and entrainment, that is, air temperature and wind speeds, also vary on subseasonal time scales. Therefore, the relation of $R B$ and vertical velocity to wind-driven currents and air temperature on subseasonal time scales was investigated as well. Finally, SSC values (estimated from $R B$ ) were used to make inter-comparisons among sites, to investigate the relation to other water quality measurements (for example, chlorophyll $a$, dissolved oxygen, and water temperature), and to determine the movement of mass vertically through the water column. 


\section{Methods}

\section{Upper Klamath Lake Field Sites}

Upper Klamath Lake has a surface area of about $230 \mathrm{~km}^{2}$, but a mean depth of only about $2.4 \mathrm{~m}$ (fig. 1). The lake trends generally from northwest to southeast. The northern end of the lake is dominated by the marshes that surround Agency Straits, the lake's connection to adjoining Agency Lake, and by the delta of the Williamson River, the largest tributary to the lake. At the southern end, the lake ends at the Link River Dam and the city of Klamath Falls, Oregon. Although most of the lake is relatively shallow, a $15-\mathrm{km}$-long trench with depths as great as about $15 \mathrm{~m}$ runs along the western side of the lake between Bare Island and Eagle Ridge to the north and Sesti Tgawaals Point to the south.

In response to water quality concerns, the U.S. Geological Survey (USGS) established a water-quality monitoring network in Upper Klamath Lake in 2002 (Wood and others, 2006). As part of ongoing research by the USGS, ADCP measurements of water velocity profiles were collected annually starting in 2003. Those ADCP measurements (Gartner and others, 2007) in conjunction with use of a numerical hydrodynamic model (Wood and others, 2008) provide understanding of horizontal water circulation in Upper Klamath Lake.

Locations of the (upward oriented) ADCP moorings in the lake were selected based on needs for calibration and validation of the numerical model used to describe wind driven circulation patterns present in the lake. During 2005 and 2006, most of the ADCPs were deployed in generally shallow regions of the lake; however, one ADCP was moored in the channel on the western side of the lake at a depth of about 12-14 m during 2005 and 2006 (fig. 1). ADCP data from 2005 include measurements from five locations; this dataset constitutes the most complete simultaneous spatial coverage of velocity measurements in Upper Klamath Lake. The deployment periods for the ADCPs were June 21September 12, 2005, and May 24-September 25, 2006.

The use of measurements of $R B$ and vertical velocity was not an objective of the deployment of these instruments in 2005, nor was it anticipated. Therefore, water quality sample collection to support estimation of SSC from $R B$ was not performed until the latter part of the 2006 field season at the two ADCP sites that were established in that year. Twenty water quality samples were collected in 2006 and analyzed for suspended solids using a gravimetric technique (SSC analytical method ASTM 3977-97) (American Society for Testing and Materials, 2000) and for percentage of organic material using a technique to determine the loss on ignition of volatile suspended solids (Fishman and Friedman, 1989). Results were used to convert backscatter measurements from the two ADCPs deployed that year to profiles of computed SSC. The water samples were taken at near-surface, mid-depth, and near-bottom locations in the water column at a deep site (ADCP1) and a shallow site (ADCP9); ADCP9 was located about $1.5 \mathrm{~km}$ south and east of the location of ADCP3 in 2005 (fig. 1).

Air temperature was recorded at a site located on the shoreline of the lake near the mouth of the Williamson River (WMR-MET). Wind speed and direction were measured from rafts at two sites on the lake [midnorth (MDN) and midlake (MDL)] and from one site on the shoreline of Howard Bay (HDB-MET). Water temperature and dissolved oxygen were measured using YSI 600XLM, 6920, or 6600 continuous water quality monitors located at Eagle Point (EPT), midtrench (MDT), and in the northern part of the lake (MDN, fig. 1). Water depths at the start of the study period were $12.5 \mathrm{~m}$ at site EPT, $14.8 \mathrm{~m}$ at site MDT, and $4.5 \mathrm{~m}$ at site MDN. Two water temperature monitors were deployed at each of these sites, one at $1 \mathrm{~m}$ from the lake bottom, and one at $1 \mathrm{~m}$ from the lake surface. Chlorophyll $a$, as a surrogate for algal biomass, was determined from weekly water samples that were collected, preserved, and later analyzed by a commercial laboratory (Hoilman and others, 2008).

\section{ADCP Measurements}

The velocity profilers used in this study were 1,200 and $600 \mathrm{kHz}$ Broadband and Workhorse ADCPs manufactured by Teledyne RD Instruments. The location of the center of the lowest measurement (bin) for each ADCP profile depended on the mooring platform design and ADCP setup. The $600 \mathrm{kHz}$ ADCP (deep station, ADCP1) was programmed with a $50 \mathrm{~cm}$ bin size, thus the center of the first bin was located at about $125 \mathrm{~cm}$ above bottom and subsequent measurements in the profile were at $50 \mathrm{~cm}$ intervals. The center of the first bin in the $1,200 \mathrm{kHz}$ datasets ranged from about 90 to $155 \mathrm{~cm}$ above bottom depending on instrument and mooring design; subsequent measurements in the profile were at $25 \mathrm{~cm}$ intervals. The ADCPs recorded water velocity measurements every 30 minutes. Sufficient individual acoustic pulses (300 pings taking about $40-50$ seconds) were averaged to decrease the theoretical standard deviation of the recorded horizontal velocities to be less than $0.7 \mathrm{~cm} / \mathrm{s}$ for each measurement. Standard deviations for vertical velocities were approximately $0.3 \mathrm{~cm} / \mathrm{s}$.

ADCPs calculate water velocity from the Doppler frequency shift or phase difference of sound backscattered from particles in the water, under the assumption that the particles travel with the velocity of the water. However, vertical particle velocity and the vertical component of water velocity may differ greatly. Thus, the ADCP has the potential to quantitatively measure the vertical motion of inorganic particles or of biological populations that actively migrate within the water column. Although the theoretical standard deviation of vertical velocity measurements in Upper Klamath Lake were the same order of magnitude as the actual measured vertical velocities for each ensemble (of averaged single acoustic pings), additional averaging served to decrease the 


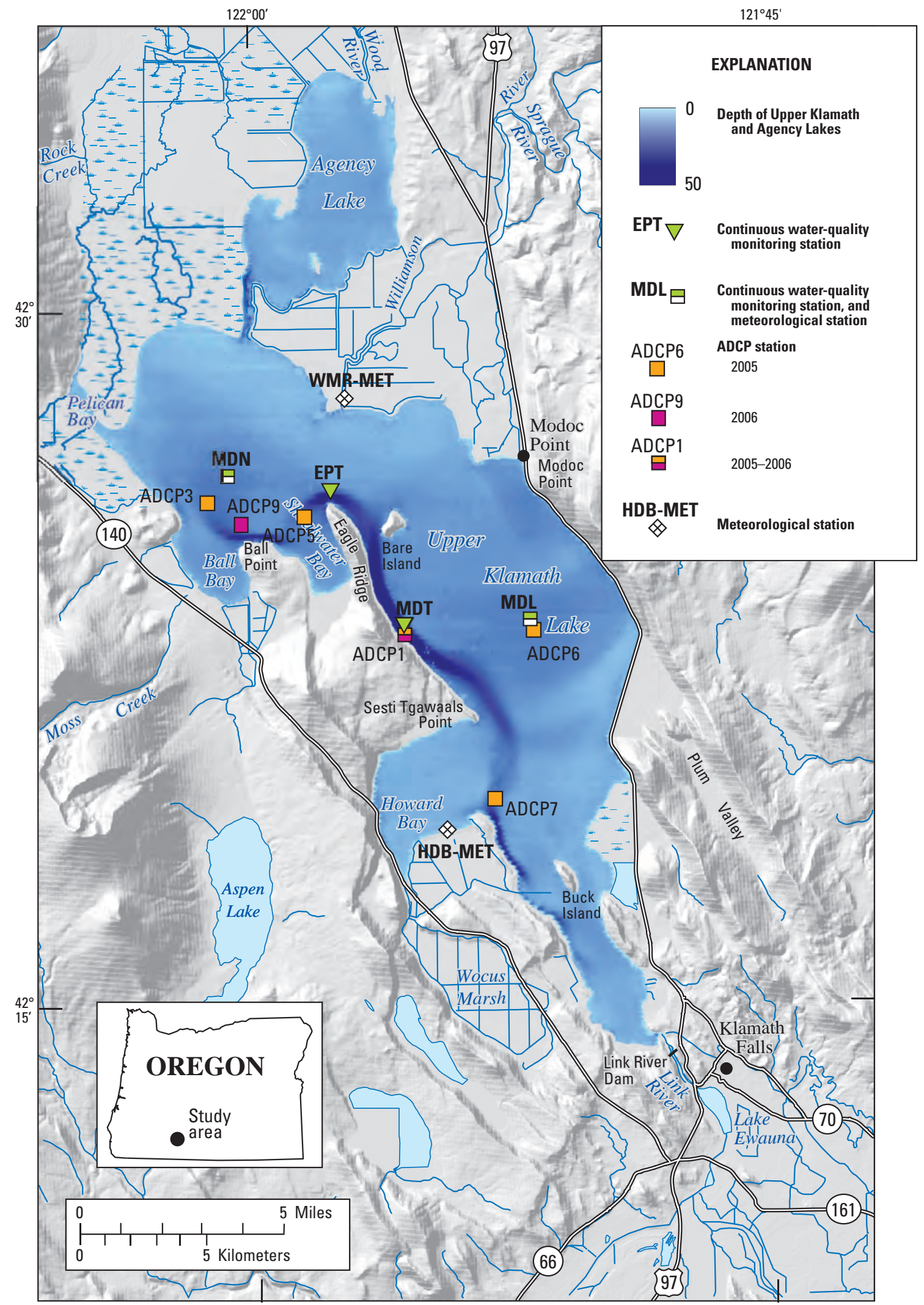

Figure 1. Study area and locations of ADCP moorings, meteorological stations, and water quality monitors, Upper Klamath Lake, south-central Oregon, 2005-06. 
standard deviation of the measurement. However, suspended material in an ADCP measurement bin may consist of a mixture of organic and inorganic material that may be actively rising, sinking, or passively moving with the water mass. It is only possible, therefore, to state that the average for the particles was rising, sinking, or stationary based on the computed vertical velocity.

A drawdown of just more than $1 \mathrm{~cm} / \mathrm{d}$ throughout the summer meant that water depths at each ADCP site were approximately $1 \mathrm{~m}$ shallower at the end of the measurement period than they were at the start. Thus, there were 2-4 more good measurement bins at the start of the deployment than there were at the end of the deployment. Therefore, in order to identify near-surface characteristics, "near-surface" time series of measurements were created from appropriate bin data from sequentially lower bins as the deployment progressed and the water depth became gradually shallower. Lake water depths at the start of the 2005 deployments were as follows: ADCP1, $14.2 \mathrm{~m}$; ADCP3, $4.3 \mathrm{~m}$; ADCP5, $5.6 \mathrm{~m}$; ADCP6, $4.4 \mathrm{~m}$; and ADCP7, $5.1 \mathrm{~m}$.

\section{Time Series Analyses}

Seasonally averaged diel cycles in wind speed, differences in water temperature between near-surface and near-bottom $\left(\Delta T^{\circ}\right), R B$, vertical velocity, horizontal current speed, and SSC were determined by averaging all valid measurements of the variable of interest collected during the (June-September) deployment at each sample time of day (for example, 00:00 h, 00:30 h, etc. for a 30-minute sampling interval). For variables measured by the ADCPs, seasonally averaged diel cycles were determined for each vertical measurement bin. Averaging over the deployment season exposed daily patterns that otherwise would be lost in large variability. The phase shift between diel cycles in $R B$ and diel cycles in wind speed, $\Delta T^{\circ}$, and horizontal current speed were found by determining the lead or lag that maximized the linear correlation between the 24-hour time series.

Correlations between $R B$ or vertical velocity and horizontal currents and water temperatures at subseasonal timescales were investigated by first filtering the time series in each bin with a series of Lanczos filters to remove high and low frequency variations to discern characteristics varying over time scales equivalent to weather patterns (Emery and Thompson, 2001). The first filter passed frequencies greater than 0.0667 cycles day $^{-1}$ (15-day period), and then a second filter passed frequencies less than 0.833 cycles day $^{-1}$ (1.2-day period). Pearson correlation coefficients were computed between the filtered $R B$ or vertical velocity and horizontal current speed in each bin.

Correlations between filtered $R B$ in each vertical bin and air temperature were examined by processing the air temperature time series with the same set of Lanczos filters. The vertical velocity or SSC in the top one-half of the water column (top one-third in the case of ADCP1) was first averaged, then passed through the series of Lanczos filters, and then correlated with filtered horizontal currents, also averaged over the top one-half of the water column, and filtered air temperature. For the purposes of determining significance of the correlations, the degrees of freedom in the filtered time series was estimated to be $\mathrm{N}=63$, which was the number of frequencies that still contained at least 1 percent of the total variance in the periodogram of the filtered time series. Using that number of degrees of freedom, rejection of the null hypothesis of no correlation would occur with 95 percent certainty at a correlation coefficient of 0.25 .

\section{Converting ADCP Backscatter to Relative Backscatter and Suspended Solids Concentrations}

The theoretical technique presented here to convert acoustic backscatter to $R B$ and ultimately to SSC is described in terms of the logarithmic form of the sonar equation, which is the typical method used for applications using ADCPs. It is well suited because commercially available ADCPs typically provide the conversion factor from raw backscatter counts to decibels, which facilitates accounting for transmission losses and empirical calibration of backscatter to SSC. The logarithmic form of the sonar equations can be inverted to obtain an expression for calculated SSC: $S S C_{\text {computed }}=$ $10^{(A+B \times R B)}$. The exponent contains the term for the $R B$, the sum of the echo level measured at the transducer plus the two-way transmission losses (Thevenot and others, 1992), that is, $R B=R L+2 T L$, where $R L$ is the reverberation level and $2 T L$ is the two-way transmission loss.

In its simplified form, the sonar equation (Urick, 1975) can be written as $R L=S L-2 T L+T S$, where $S L$ is the source level, which is the intensity of emitted signal that is known or measurable, and TS is the target strength, which is dependent on the ratio of wavelength to particle diameter. All variables are measured in decibels. In terms of ADCP parameters, $R L=K_{c}\left(E-E_{r}\right)$, where $E$ is ADCP echo intensity recorded in counts, $E_{r}$ is ADCP received signal strength indicator (RSSI) reference level (the echo baseline when no signal is present), in counts, and $K_{c}$ is the RSSI scale factor used to convert counts to decibels. $K_{c}$ varies among instruments and transducers and has a value of $0.35-0.55$ (Deines, 1999). The two-way transmission loss is defined as $2 T L=2\left(\alpha_{w}+\alpha_{s}\right) R+$ $20 \log _{10}(R)$, where $R$ is the range to the ensonified volume, in meters; $\alpha_{w}$ is an absorption coefficient for water; $\alpha_{s}$ is an attenuation coefficient accounting for viscous and scattering losses due to suspended particles, both in decibels per meter; $2\left(\alpha_{w}+\alpha_{s}\right) R$ is the combined transmission loss due to water absorption and sediment attenuation; and $20 \log _{10}(R)$ is the loss due to spreading. The absorption coefficient for water is a function of acoustic frequency, salinity, water temperature, and pressure (Schulkin and Marsh, 1962). Because of non-spherical spreading in the transducer near field, the spreading loss is different in near and far transducer fields. 
The transition between near and far transducer fields is called the critical range, $R_{c r i t} . R_{c r i t}=\pi \alpha_{t} \lambda$ where $\alpha_{t}$ is the transducer radius, in centimeters, and $\lambda$ is the acoustic wavelength. The near-field correction for spreading loss can be easily calculated as described in Downing and others (1995).

Gartner (2004) describes a practical approach to compute a time series of SSC from a time series of ADCP acoustic backscatter. First, the $R B$ is determined, and the $\log _{10}$ of the SSC measurements, $S S C_{\text {measured }}$, are calculated. The needed calibration coefficients consisting of slope, $B$, and intercept, $A$, for a regression between $\log _{10}\left(S S C_{\text {measured }}\right)$ and $R B$ is determined such that $\log _{10}\left(S S C_{\text {measured }}\right)=A+B \times R B$. The theoretical value for slope, $B$, is 0.1 and the intercept is a function of particle and instrument characteristics; values are appropriate for a concentration of uniform particles of the same mass and other properties (Thevenot and others, 1992). After values of $A$ and $B$ are determined for the distribution of particles in the field, new time series of profiles of SSC can be computed from ADCP RB profiles utilizing the exponential form of the equation, $S S C_{\text {computed }}=10^{(A+B \times R B)}$. An alternative to using regression to determine $A$ and $B$ is to use the theoretical value of slope, $B$, equal to 0.1 , and to calculate the intercept based on the $\log _{10}$ of the measured SSC and the $R B$ from $\mathrm{A}=\log _{10}(S S C)-0.1 \times R B$.

To determine appropriate calibration coefficients for data from Upper Klamath Lake, water quality samples were analyzed for mass concentration and percentage of organic material. Mass concentration of the 20 water quality samples collected in 2006 ranged from about 4 to $43 \mathrm{mg} / \mathrm{L}$, but results from replicate pairs ranged from 0 to 100 percent (Gartner and others, 2007). SSC comprises both organic and inorganic fractions in Upper Klamath Lake. Because calibration coefficients depend on size and other characteristics of the suspended particles, temporal or spatial (including vertical) variations in the ratio of organic to inorganic material is of interest. The organic fraction dominates in Upper Klamath Lake; the average organic fraction for all 20 water samples was about 77 percent (standard deviation about 11 percent).

Coefficients for use in converting RB measured in 2006 to estimates of profiles of SSC were calculated several ways, including determining an average slope and average intercept, using a theoretical slope (0.1) and single average intercept, and using a theoretical slope (0.1) and intercepts calculated from near-surface, mid-depth, and near-bottom samples for the shallow and for the deep sites. Standard deviations of the differences between measured and estimated SSC for the three techniques were about $10.2,22.8$, and $9.9 \mathrm{mg} / \mathrm{L}$, respectively. The organic fraction was generally somewhat lower near-bottom than it was near-surface but still predominated. Although some spatial and temporal variations existed in SSC and the percentage of organic material, variations were small and the samples insufficient to calculate reliable trends. Thus, the theoretical slope (0.1) and different average intercepts for the deep and shallow sites were used but the intercepts were not varied with vertical position in the water column when estimating new profiles of SSC. For the four shallowest sites in 2005, SSC was computed from ADCP backscatter measured in 2005 using the theoretical slope (0.1) and the average intercept determined for the single shallow station in 2006 (-7.08). For the deep site in 2005, the theoretical slope (0.1) and the average of the intercept determined for the deep station at the same location in 2006 was used (-6.92). (When this technique was applied to the 2006 datasets, the standard deviation was $19.1 \mathrm{mg} / \mathrm{L}$.) $1,200 \mathrm{kHz}$ ADCPs were used at all shallow stations and a $600 \mathrm{kHz}$ ADCP was used at the deep station.

No compensation was made for potential variations in ADCP transmit power (Deines, 1999; Wall and others, 2006) from changes in internal battery voltage during the deployment. The average of the backscatter from all four ADCP acoustic beams was used in calculations as the beams have different source levels and sensitivities. Averaging also helps to overcome the impact of patchiness of the suspended material. In addition, transmission losses from particle attenuation were not accounted for in computing SSC.

\section{Wind, Currents, and Water Temperature}

Analyses of seasonally averaged wind graphs indicated that winds over Upper Klamath Lake displayed diel patterns (Gartner and others, 2007). During the 2005 field season, minimum wind speeds occurred during late morning (about $1.75 \mathrm{~m} / \mathrm{s}$ at $10: 15 \mathrm{~h}$ at site $\mathrm{MDN}$, about $3.0 \mathrm{~m} / \mathrm{s}$ at $11: 45 \mathrm{~h}$ at site $\mathrm{HDB}$, and about $2.25 \mathrm{~m} / \mathrm{s}$ at $12: 15 \mathrm{~h}$ at site MDL); maximum wind speeds occurred during late evening (about $6.0 \mathrm{~m} / \mathrm{s}$ at $20: 45 \mathrm{~h}$ at site MDN, about $5.5 \mathrm{~m} / \mathrm{s}$ at $19: 45 \mathrm{~h}$ at site HDB, and about $6.5 \mathrm{~m} / \mathrm{s}$ at 21:30 $\mathrm{h}$ at site MDL). [All times shown are referenced to Pacific Daylight Standard Time (PDST).] Upper Klamath Lake is a wind-driven system with little river inflow, thus horizontal water currents are expected to be a function of wind patterns.

Velocity measurements by ADCPs showed that a generally clockwise circulation pattern was established in Upper Klamath Lake under prevailing (northwest to north) wind conditions (Gartner and others, 2007; Wood and others, 2008). Although all ADCP records generally showed diel patterns in the water currents, the times of day of minimum and maximum current speeds were spatially variable in the lake because of the effects of bathymetry and geometry on water motion. The closest correspondence between times of maximum and minimum winds and maximum and minimum horizontal currents generally occurred at the southern end of the deep-water trench at site ADCP7. Maximum and minimum currents at site ADCP7 occurred within 1-2 hours of the corresponding wind events both near-surface and near-bottom. The largest offsets occurred in the middle of the lake at site ADCP6 (near MDL) where water currents led winds by 6-10 hours near-surface and by 2-6 hours near-bottom. Thus, even though water currents in the lake are wind-driven, the response of the water currents to the wind varies in timing and magnitude around the lake. 
Water temperature in the lake had a strong diel cycle, particularly near the surface. At times of maximum nearsurface water temperature, the difference in water temperature between the near-surface and near-bottom of the water column was enough to provide resistance to mixing, particularly at the deepest sites in the trench. On most days, the water temperature difference was eroded in late evening or early morning by a combination of high winds and cool air temperatures (Wood and others, 2006; Hoilman and others, 2008). The $\Delta T^{\circ}$ at sites MDT, MDN, and EPT were used to determine the seasonally averaged diel patterns (fig. 2). The maximum $\Delta T^{\circ}$ was greatest at site MDT, the site closest to site ADCP1 and in the deepest water, and occurred there the latest in the day $(19: 00 \mathrm{~h})$. The maximum $\Delta T^{\circ}$ at site EPT, the closest to site ADCP5, was less than at site MDT and occurred at 18:00 $\mathrm{h}$. The maximum $\Delta T^{\circ}$ at site MDN, which was closest to site ADCP3 and in shallower water than sites EPT and MDT, was approximately the same magnitude as at site EPT but occurred earlier in the day at 16:00 $\mathrm{h}$. Seasonally averaged diel patterns in $\Delta T^{\circ}$ were not available near sites ADCP6 and ADCP7; values at site MDN were used when necessary for analyses because the water depths at sites ADCP6 and ADCP7 were similar to that at site MDN.

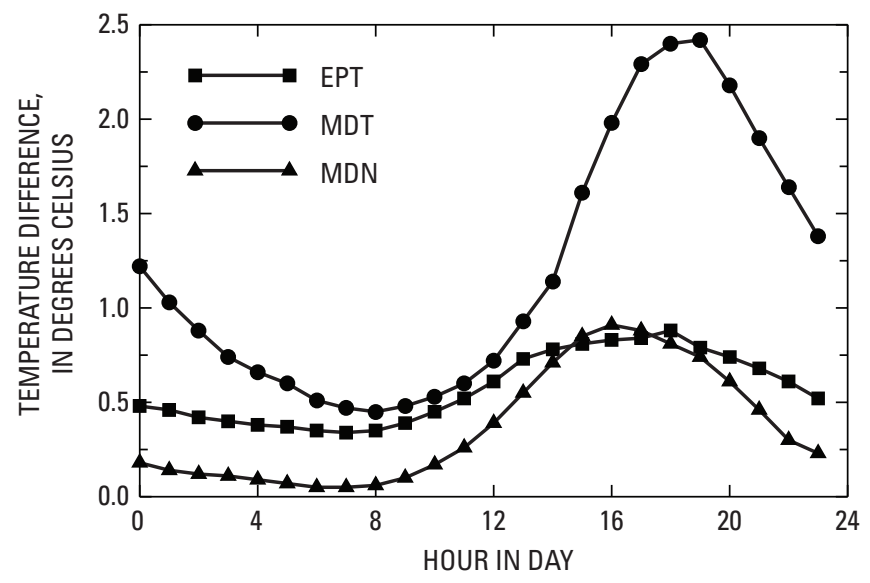

Figure 2. Diel patterns in the difference between water temperatures measured near-surface and near-bottom at sites MDN (4.5 m depth), EPT (12.5 m depth), and MDT (14.8 $\mathrm{m}$ depth) in Upper Klamath Lake, south-central Oregon. Diel patterns are derived from an average of hourly monitor measurements between June 2, 2005, and October 9, 2005. Minimum temperature differences occur between 07:00 $\mathrm{h}$ (sites MDN and EPT) and 08:00 $\mathrm{h}$ (site MDT); maximum temperature differences occur between 16:00 $\mathrm{h}$ (site MDN) and 19:00 $\mathrm{h}$ (site MDT). The maximum standard error of the estimate of the average temperature difference is $0.07^{\circ} \mathrm{C}$ at sites EPT and MDN, and $0.14^{\circ} \mathrm{C}$ at site MDT.

\section{Relative Backscatter Intensity}

Seasonally averaged diel cycles of $R B$ showed that there was a time in early- to mid-morning when vertical variation in $R B$ was at a minimum and a time in mid- to late-afternoon when vertical variation in $R B$ was at a maximum (fig. 3 ). Times of minimum (about 8:00-9:00 h) and maximum (about 15:00-19:00 h) RB near-surface occurred nearly simultaneously at the five ADCP sites (ig. 3 ), but varied widely near-bottom. At the deep site, ADCP1, the minimum $R B$ near-bottom lagged the maximum near-surface by about 2 hours. At the other four ADCP sites, located in shallower water than site $\mathrm{ADCP} 1$, the minimum $R B$ in the lower part of the water column preceded the maximum at the surface by several hours. The maximum $R B$ at the surface at sites ADCP3, ADCP6, and ADCP7 appears to spread downward during the evening and early morning hours and displace the near-bottom minimum, moving it closer to the bottom (fig. 3).

In addition, there was good correspondence between the timing of diel cycles of winds and $R B$ at the surface. Comparisons of diel wind and $R B$ cycles at the five ADCP sites showed that $R B$ preceded corresponding wind by about 2-4 hours. The average correlation coefficient, $R$, for the five sets of data was 0.92 (all $p<0.0001$ ). Timing of patterns was far more variable near-bottom where $R B$ lagged winds by $2-10$ hours (average $R=0.88$; all $p<0.0001$ ). The shortest lag was at site ADCP6; the longest lags were at sites ADCP1 and ADCP7.

In contrast, there was no consistent relation between the diel cycles of the horizontal currents and $R B$. The timing between $R B$ and water currents near-surface was between a 10-hour lead at site ADCP5 and a 9-hour lag at site ADCP3 (average $R=0.78$; all $p<0.0002$ ). Similarly, the correspondence between water currents and $R B$ also varied widely near-bottom, ranging from a 1-hour lead at site ADCP5 to a 9-hour lag at site ADCP7 (average $R=0.65$; all $p<0.0005$ except site ADCP6 where $R=0.21$ and $p=0.14$ ).

The best correspondence and smallest phase difference occurred between the diel cycles of $\Delta T^{\circ}$ and $R B$ near-surface. Comparisons of diel cycles of $R B$ and $\Delta T^{\circ}$ showed little or no phase difference near-surface ( $R B$ lagged $\Delta T^{\circ}$ by $0-1$ hour; average $R=0.93$; all $p<0.0001)$. Near-bottom, $R B$ lagged $\Delta T^{\circ}$ by $8-14$ hours (average $R=0.87$; all $p<0.0001$ ).

The $R B$ was most uniform through the water column in the morning, coincident with minimum temperature stratification, and most surface-intensified in the afternoon, coincident with the maximum temperature stratification. 


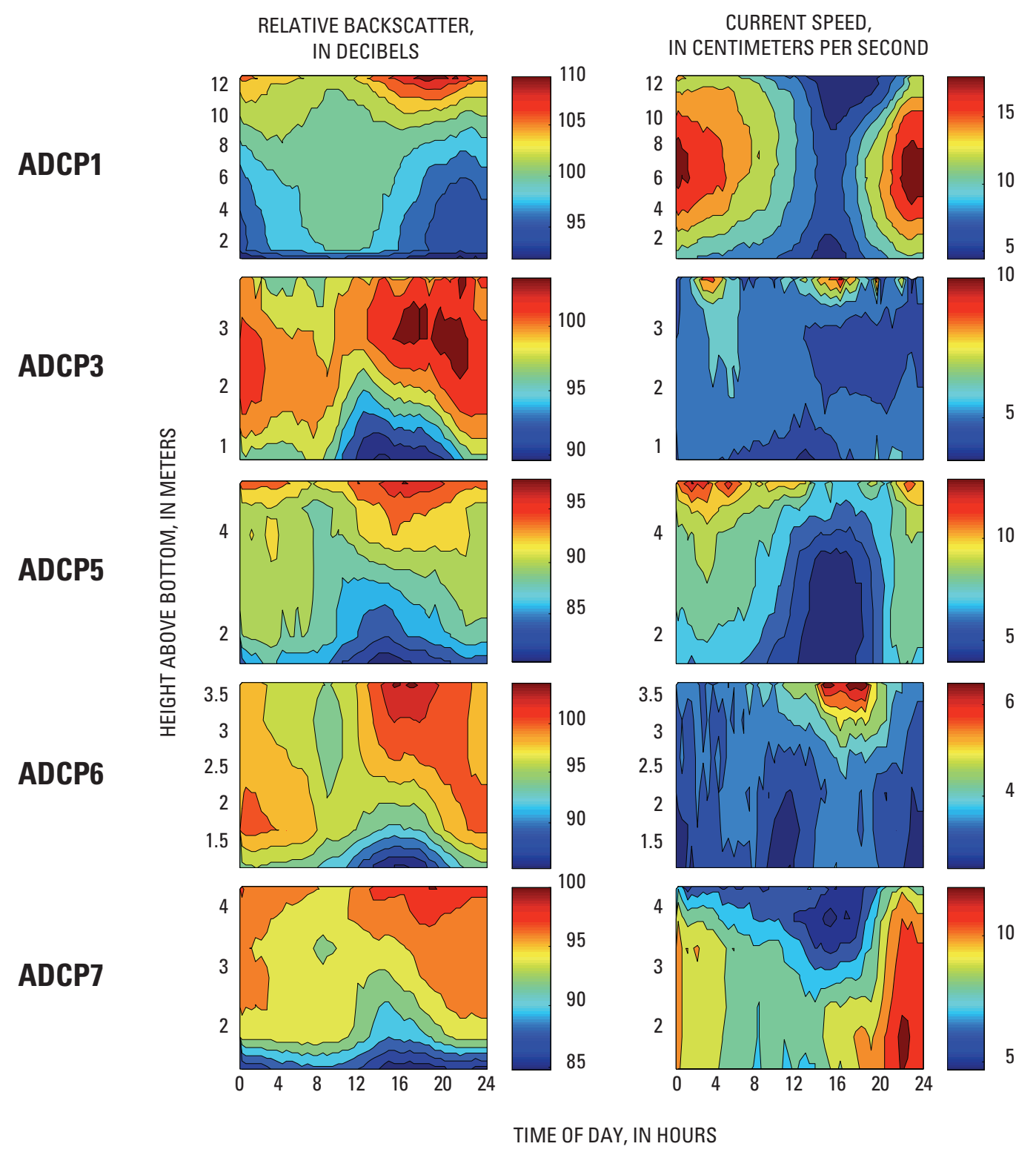

Figure 3. Daily variations in relative backscatter and water current speed at the five ADCP deployment sites, Upper Klamath Lake, south-central Oregon, 2005. Diel patterns are derived from an average of 30-minute ADCP measurements between June 21, 2005, and September 12, 2005. The maximum standard error of the estimate of mean relative backscatter as a function of hour in the day and depth in the water column is $0.9 \mathrm{~dB}, 6.3 \mathrm{~dB}, 1.2 \mathrm{~dB}, 1.4 \mathrm{~dB}$, and $0.8 \mathrm{~dB}$ for ADCP1, ADCP3, ADCP5, ADCP6, and ADCP7, respectively. The maximum standard error of the estimate of mean horizontal current speed as a function of hour in the day and depth in the water column is $1.7,5.2,2.0,1.5$, and $1.7 \mathrm{~cm} / \mathrm{s}$ for sites ADCP1, ADCP3, $A D C P 5, A D C P 6$, and ADCP7, respectively. 
The diel cycle in $R B$ was more closely aligned to the timing of $\Delta T^{\circ}$ and, to a lesser extent, to diel wind cycles than to the timing of the maximum and minimum in currents. Daily surface intensification of $R B$ was consistent with the accumulation of buoyant particles, but the diel cycle was about 12 hours out of phase with the theoretical light-driven movement of a buoyant cyanobacteria, in which colonies increasingly rise as darkness progresses and increasingly sink as light progresses. (Times of minimum and maximum $R B$ near-surface were about 8:00-9:00 h and 15:00-19:00 h, respectively.)

At subseasonal time scales, correlations between filtered $R B$ and water currents were positive through most of the water column at all but site ADCP3, the shallowest ADCP site (fig. 4). At sites ADCP1, ADCP3, ADCP5, and ADCP7, the correlations decreased away from the bottom and (except at ADCP5) became negative within the upper bins, indicating a dispersal of mass away from the surface to deeper in the water column and, possibly, increased resuspension of bed material with increased water current speeds. The negative correlations near-surface were consistent with a near-surface mixed layer of approximately $1 \mathrm{~m}$ at sites ADCP1 and ADCP7, and closer to $1.75 \mathrm{~m}$ at site $\mathrm{ADCP} 3$, in which mass decreased as water current speeds increased. The lack of negative correlations in upper bins at site ADCP5 may indicate a thin surface mixed layer within the zone that was unmeasured by the ADCP $(<0.5 \mathrm{~m})$. The correlations at site ADCP6 were weak with little vertical variation, suggesting that the relation between $R B$ and currents may be a function of advection rather than entrainment.

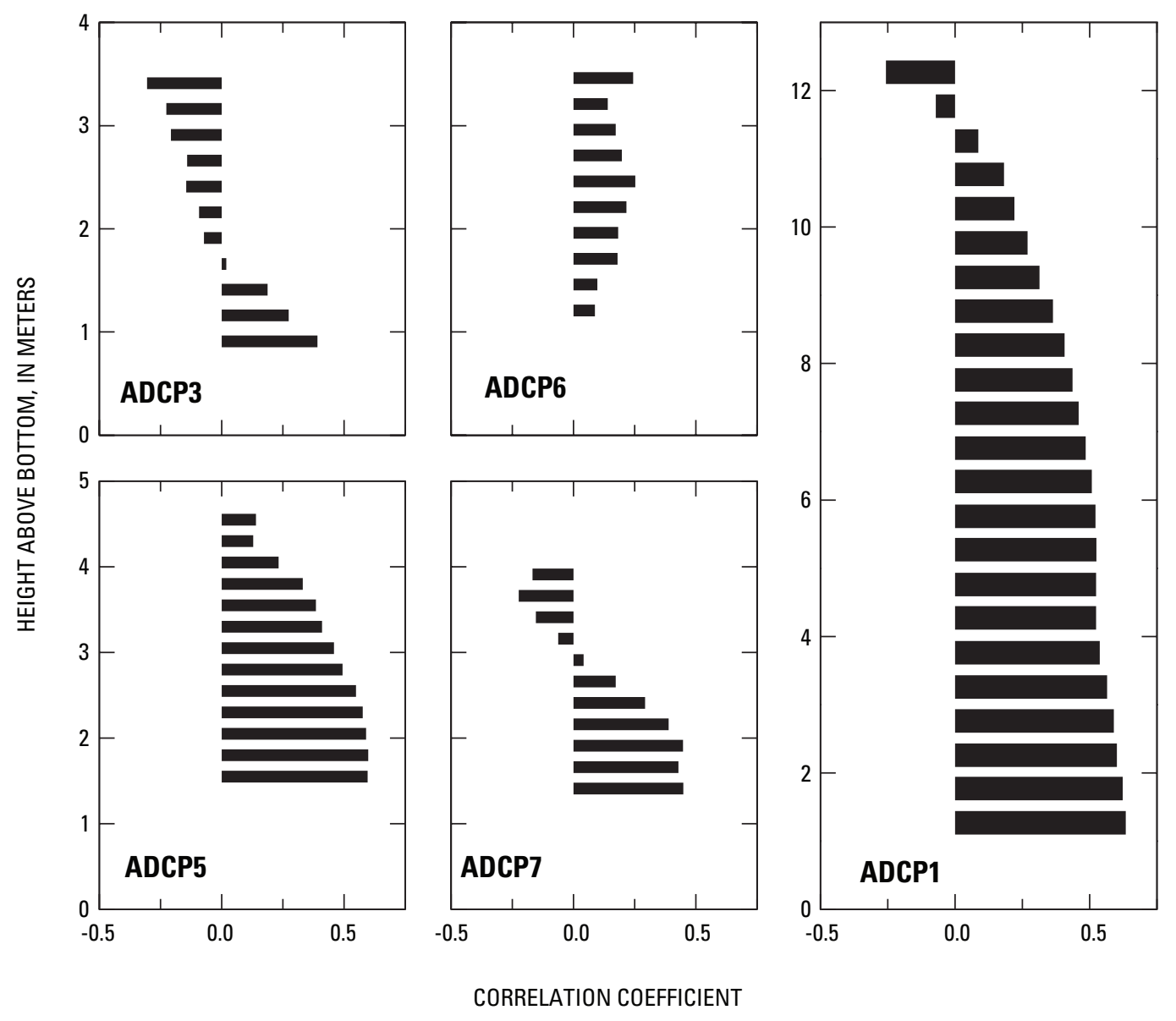

Figure 4. Profiles of correlation between water current speed and relative backscatter at subseasonal time scales, at five sites where ADCPs were deployed, Upper Klamath Lake, southcentral Oregon, 2005. Correlation coefficients $>0.25$ are significant $(p<0.05)$. 
Correlations between filtered $R B$ and air temperature at subseasonal time scales (fig. 5) were largely a reverse of the correlations with currents (ig. 4 ). To some extent, this results from negative correlations between water current speeds and air temperature (weather systems that are accompanied by lower than average air temperatures tend to be associated with stronger than average winds and resulting wind-driven currents). The correlations displayed in figure 5 also are consistent with the effect that air temperature has on water column mixing. Increased water temperature in the upper water column (from warmer air temperature) increases the resistance to mixing; colder air has the opposite effect. Negatively buoyant particles settle out of the water column and positively buoyant particles rise to the surface when mixing is suppressed. Correlations between $R B$ and air temperature were negative through most of the water column at all sites except ADCP7, where the correlation was positive in the upper one-half of the water column (fig. 5). The negative correlation decreased moving away from the bottom and became positive nearer the surface at sites ADCP1, ADCP3, ADCP6, and ADCP7, suggesting the accumulation of mass in the upper water column as air temperature increased. This is consistent with the near-surface correlations between $R B$ and water current speeds (fig. 4) at sites ADCP1, ADCP3, and ADCP7.

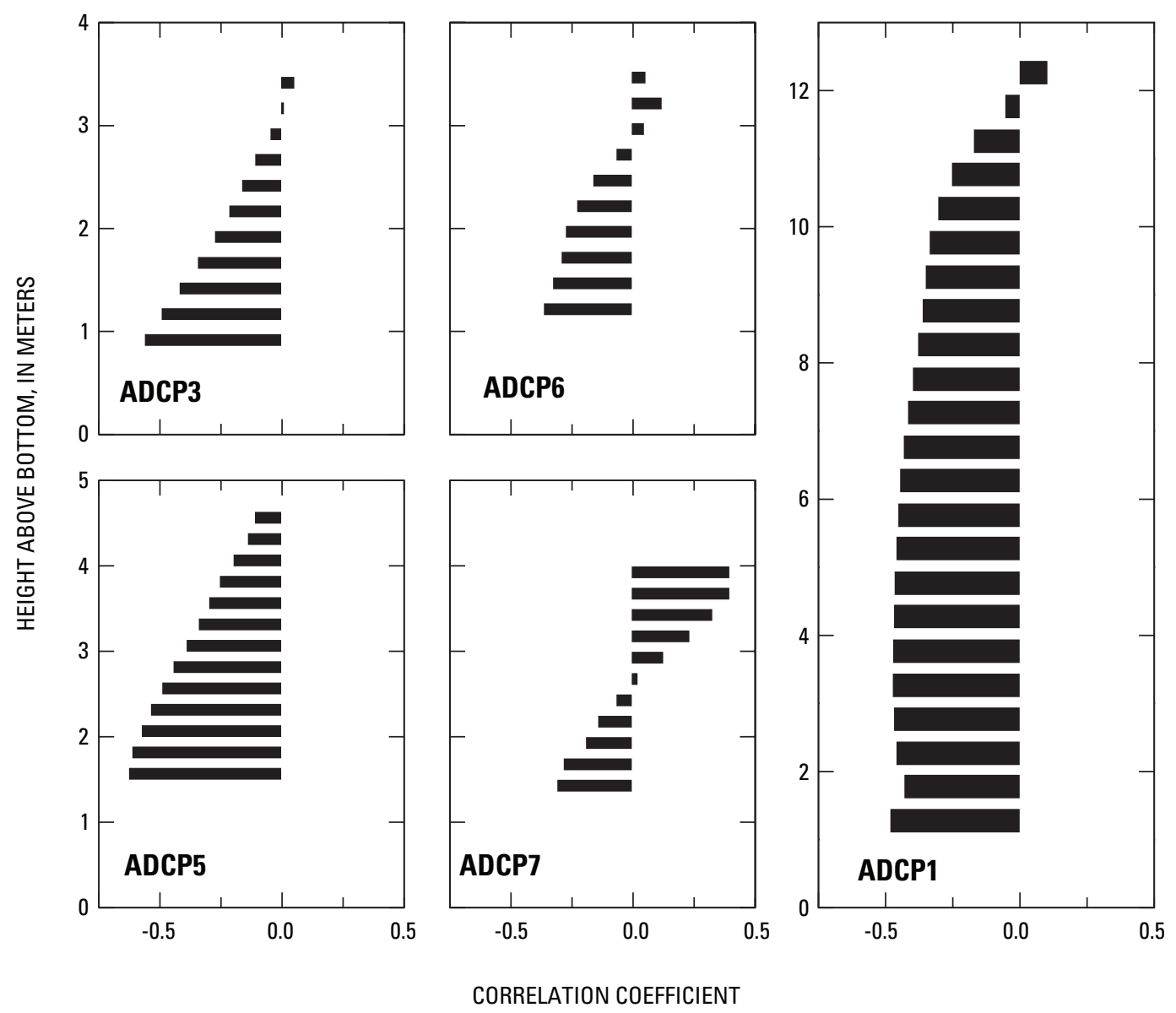

Figure 5. Profiles of correlation between air temperature and relative backscatter at subseasonal time scales, at five sites where ADCPs were deployed, Upper Klamath Lake, south-central Oregon, 2005. Correlation coefficients $>0.25$ are significant $(p<0.05)$. 


\section{Vertical Velocities}

The analysis of the vertical velocities was limited to the top one-half of the water column (top one-third at site ADCP1) in order to avoid any influence of local bottom topography. This was done by vertically averaging the velocities over appropriate upper bins.

Seasonally averaged vertical velocities were negative (indicating sinking) throughout the day at sites ADCP5, ADCP6, and ADCP7. Only site ADCP1 included a sustained period of positive (rising) velocity from about 12:00 to 24:00 h. Site ADCP3 displayed no clear trend (fig. 6). The diel cycles were most pronounced at sites ADCP1 and ADCP5 where the daily minimum vertical velocity was negative and occurred nearly simultaneously with the maximum surface current speed (site ADCP5), or 2-3 hours later (site ADCP1). Daily minimum vertical velocities occurred several hours prior to minimum $\Delta T^{\circ}$. At site ADCP5, the daily maximum vertical velocity was still negative, indicating sinking, and occurred just prior to minimum surface current speed and the maximum $\Delta T^{\circ}$. At site $\mathrm{ADCP} 1$, the daily maximum vertical velocity was positive, indicating rising, and followed minimum surface current speed and was coincident with the maximum $\Delta T^{\circ}$. At both sites, the maximum upward (site ADCP1) or minimum downward (site ADCP5) vertical velocity was coincident with the near-surface maximum in $R B$ (fig. 3). Similar to diel patterns of $R B$, the diel patterns of vertical velocity also were out of phase with the theoretical model for light-driven vertical movement of buoyant cyanobacteria colonies.

Pearson correlation coefficients between filtered vertical velocities and horizontal current speeds (at subseasonal time scales) in the top one-half of the water column were significant and negative at sites ADCP1 and ADCP5 (table 1). These negative correlations were consistent with weaker currents resulting in disentrainment of positively buoyant particles, and with the correlation between $R B$ and horizontal current speeds at site ADCP1 that showed more accumulation of mass near the surface with weaker currents. The correlation between near-surface vertical velocity and horizontal current speeds also was significant at site ADCP7, but the correlation was positive, suggesting that sinking particles were disentrained as horizontal current speeds decreased.

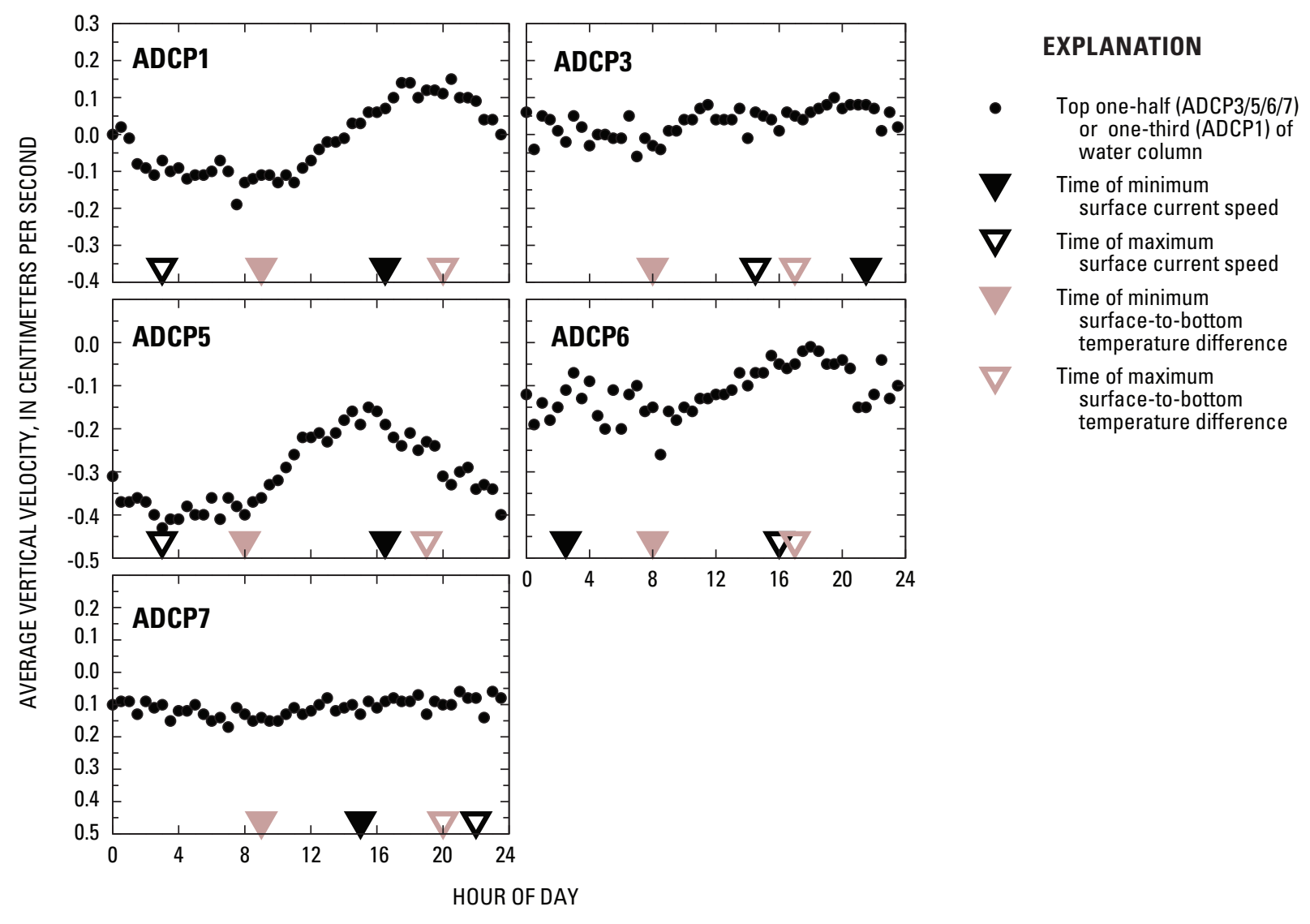

Figure 6. Seasonally averaged diel patterns in near-surface vertical velocity at five ADCP sites, Upper Klamath Lake, south-central Oregon, 2005. The time of maximum and minimum near-surface current speeds and maximum and minimum water temperature top-to-bottom differences are shown for reference. Diel patterns are derived from an average of 30-minute ADCP measurements between June 21 and September 12, 2005. The maximum standard error of the estimate of average vertical velocity is $0.03 \mathrm{~cm} / \mathrm{s}$ for sites ADCP1, ADCP3, and ADCP7, and $0.05 \mathrm{~cm} / \mathrm{s}$ for sites ADCP5 and ADCP6. 
Table 1. Correlation coefficients between vertical velocities and horizontal currents and air temperature, Upper Klamath Lake, south-central Oregon.

[Locations of ADCP sites are shown in figure 1. Vertical velocities and horizontal current speeds were averaged over the top one-half (top one-third at ADCP1) of the water column. Air temperature was measured at site WMRMET. Time series were filtered to pass periods between 1.2 and 15 days. Correlation coefficients greater than 0.25 are significant and indicated by boldface type $(p<0.05)]$

\begin{tabular}{ccc}
\hline \multirow{2}{*}{ ADCP site } & \multicolumn{2}{c}{ Correlation of vertical velocities with } \\
\cline { 2 - 3 } & $\begin{array}{c}\text { Horizontal } \\
\text { current speeds }\end{array}$ & Air temperature \\
\hline ADCP1 & $\mathbf{- 0 . 5 2}$ & $\mathbf{0 . 4 7}$ \\
ADCP3 & .15 & .01 \\
ADCP5 & -.43 & .17 \\
ADCP6 & -.09 & .19 \\
ADCP7 &. $\mathbf{4 4}$ & -.10 \\
\hline
\end{tabular}

The correlations between near-surface vertical velocities and air temperature generally were small with the exception of those at site ADCP1, where the correlation was positive (table 1). The sign of the correlation indicates that, when mixing was suppressed by high surface temperature, positively buoyant particles were preferentially disentrained. This is consistent with the results of the correlation of $R B$ with air temperature (fig. 5), which indicated the potential for accumulation of mass near the surface at high air temperatures. Thus, at least at the deepest site (ADCP1), a tendency for mass to accumulate near surface with both weak horizontal currents and high temperatures was supported by the behavior of both $R B$ and vertical velocities.

\section{Suspended Solids Concentration}

Although using $R B$ to discern seasonal, subseasonal, and diel variations of suspended material is enlightening, $R B$ does not allow direct comparisons among measurements by different instruments or locations. However, use of measured or computed SSC (in units of mass/volume rather than $\mathrm{dB}$ ) does allow quantitative comparisons between datasets, meaningful comparisons to other water quality variables, and investigation of the movement of mass through the water column. For this reason, profiles of SSC were computed using acoustic backscatter measurements at the five ADCP sites in 2005.

The time series of SSC calculated from $R B$ show distinct differences between the sites (fig. 7). Overall through the season, the depth-averaged concentrations were highest at the deepest site, ADCP1. Concentrations were second highest at the northernmost site, ADCP3, but were lowest at ADCP5, another site in the northern part of the lake. These relative concentrations were consistent with the chlorophyll $a$ samples collected at four sites during the 2005 season. The median chlorophyll $a$ concentrations of 12 samples collected between June and September at site MDT (near site ADCP1), site MDN (near site ADCP3), site EPT (near site ADCP5), and site MDL (near site ADCP6) were 122.5, 99.0, 36.5, and $59.7 \mu \mathrm{g} / \mathrm{L}$, respectively. The correspondence between the two variables was further tested with linear regression between the depth-averaged chlorophyll $a$ and the median value of the computed depth-averaged SSC during the 2 hours surrounding the time of sample collection and at the most closely situated ADCP site (table 2). At the two sites that were coincident with a water quality site, sites ADCP1 and ADCP6, the correlation coefficients were 0.46 and 0.63 , respectively. At the other two sites, which were each located about $1.5 \mathrm{~km}$ from the nearest water quality site, the correlation coefficients were 0.47 and 0.43 at sites ADCP3 and ADCP5, respectively. All correlation coefficients were at least weakly significant $(p<0.16)$.

The computed SSC also shows some correspondence with continuous measurements of dissolved oxygen (DO) from monitors located at the water quality sites, two of which are shown in figure 7. The seasonal minimum in DO at site MDN was an indicator of a severe decline in the AFA bloom between the last week in July and the first week in August (Hoilman and others, 2008). The lowest DO values during this time coincided with low SSC at sites ADCP1, ADCP3, and ADCP5. A common characteristic of a major bloom decline in the lake is that it is most severe in the deep trench and in the northern part of the lake (Wood and others, 2006; Hoilman and others, 2008; Lindenberg and others, 2008), which is consistent with the fact that the late July/early August minimum in SSC was most prominent at the sites in the northern part of the lake (sites ADCP3 and ADCP5) and in the trench (site ADCP1), and was least prominent at site ADCP6 (fig. 7). In order to quantify the correspondence between SSC and DO, the correlation coefficient between the daily median value of depth-averaged SSC and the daily median value of $\mathrm{DO}$, measured $1 \mathrm{~m}$ from the bottom of the lake at the closest water quality site, was calculated (table 2). At all sites, the correlations with DO were significant with $p<0.02$.

Table 2. Correlations of computed suspended solids concentrations (SSC) at ADCP sites with chlorophyll $a$ and dissolved oxygen at water quality sites, Upper Klamath Lake, south-central Oregon.

[Locations of sites are shown in figure 1. All correlations of SSC with chlorophyll $a$ are at least weakly significant $(p<0.16)$ and all correlations of SSC with dissolved oxygen are significant $(p<0.02)$. ADCP, acoustic Doppler current profiler; $\mathrm{N}$, number; $\geq$, equal to or greater than]

\begin{tabular}{|c|c|c|c|}
\hline \multirow[b]{2}{*}{$\begin{array}{l}\text { ADCP } \\
\text { site }\end{array}$} & \multirow[b]{2}{*}{$\begin{array}{l}\text { Water } \\
\text { quality } \\
\text { site }\end{array}$} & \multicolumn{2}{|c|}{ Correlation of SSC with } \\
\hline & & $\begin{array}{l}\text { Depth-averaged } \\
\text { chlorophyll a } \\
(\mathrm{N} \geq 12)\end{array}$ & $\begin{array}{c}\text { Daily median } \\
\text { dissolved oxygen } \\
(\mathrm{N} \geq 78)\end{array}$ \\
\hline ADCP1 & MDT & 0.46 & 0.30 \\
\hline ADCP3 & $\mathrm{MDN}$ & .47 & .45 \\
\hline ADCP5 & EPT & .43 & .34 \\
\hline ADCP6 & MDL & .63 & .27 \\
\hline
\end{tabular}



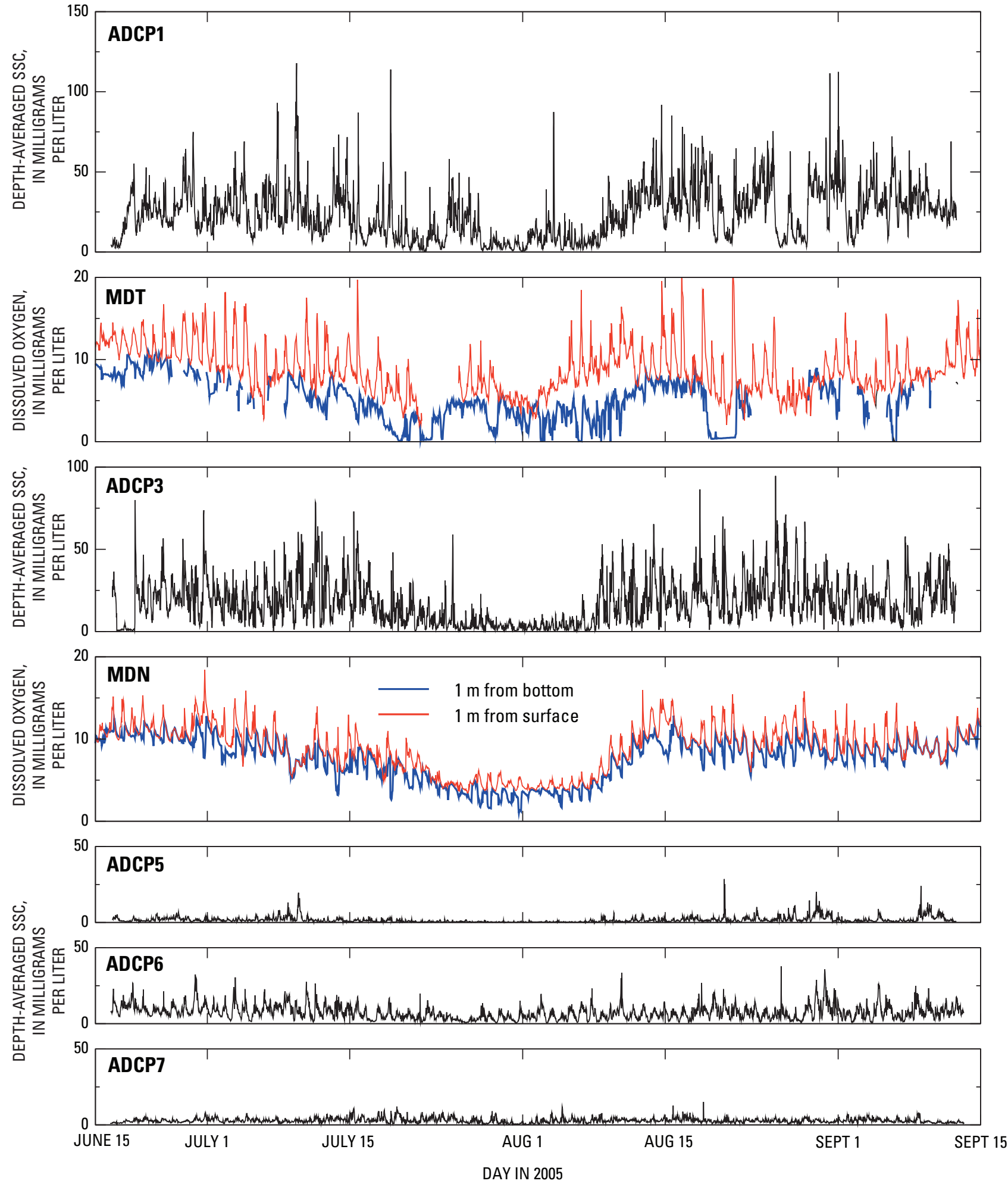

Figure 7. Depth-averaged (computed) suspended solids concentration (SSC) at five ADCP sites and dissolved oxygen at two water quality sites (MDT and MDN), Upper Klamath Lake, Oregon, June 21-September 12, 2005. 
Computed SSC can provide insight into how mass moves vertically through the water column at diel time scales. The computed SSC at each bin in the vertical water column was used to calculate the fraction of total water column mass in the upper and lower one-half of the water column as a function of time (upper one-third and lower two-thirds of the water column at site ADCP1). Surface intensification is indicated when the fraction of water column mass in the upper one-half of the water column (upper one-third at site ADCP1) is greater than 50 percent (33 percent at site ADCP1); bottom intensification is indicated when the fraction of water column mass in the lower portion of the water column is greater than 50 percent (67 percent at site ADCP1). A typical 10-day period of record shows that mass was concentrated in the upper portion of the water column during those hours of the day when there was some thermal stability in the water column. As the surface started to cool and winds increased, the water column became well-mixed (fig. 8) from decreased stratification and increased turbulence. This short period of record is typical of the longer record, in which surface intensification as a daily phenomenon was common and bottom intensification was uncommon, but occurred occasionally at site ADCP1.

When computed SSC was averaged over the season to produce the seasonally averaged diel cycle, a clear pattern of afternoon surface intensification emerged at each site (fig. 9). The mass in the top one-half of the water column (top one-third at site ADCP1) reached a maximum near the time corresponding to the maximum $\Delta T^{\circ}$. The mass in the bottom

Table 3. Average mass and average daily range in mass of suspended solids at ADCP sites, Upper Klamath Lake, southcentral Oregon.

[Locations of sites are shown in figure 1. ADCP, acoustic Doppler current profiler; $\mathrm{m}$, meter; $\mathrm{mg} / \mathrm{m}^{2}$, milligram per square meter]

\begin{tabular}{cccc}
\hline $\begin{array}{c}\text { ADCP } \\
\text { site }\end{array}$ & $\begin{array}{c}\text { Mean depth } \\
\text { during } \\
\text { deployment } \\
(\mathbf{m})\end{array}$ & $\begin{array}{c}\text { Average mass } \\
\left(\mathbf{m g} / \mathbf{m}^{\mathbf{2}}\right)\end{array}$ & $\begin{array}{c}\text { Average range } \\
\text { in mass } \\
\left(\mathbf{m g} / \mathbf{m}^{\mathbf{2}}\right)\end{array}$ \\
\hline ADCP1 & 13.7 & 549 & 107 \\
ADCP3 & 3.9 & 186 & 132 \\
ADCP5 & 5.1 & 22 & 13 \\
ADCP6 & 4.0 & 75 & 69 \\
ADCP7 & 4.5 & 32 & 13 \\
\hline
\end{tabular}

one-half (two-thirds at site ADCP1) reached a minimum a few hours ahead of the maximum in mass in the top one-half of the water column at all sites except site ADCP1, where it instead reached a minimum a few hours later than the maximum in mass in the top one-half. The depth-integrated mass was greatest at site ADCP1; however, the average daily change in mass was the smallest percentage of the total mass (about 19 percent, table 3 ), whereas the average daily change in mass was the largest percentage of the total mass at site ADCP6 (about 92 percent) and site ADCP3 (about 71 percent), the two most shallow sites.

Pearson correlation coefficients between depth-integrated computed SSC and horizontal current speeds at subseasonal time scales were positive and significant at sites ADCP1, ADCP5, and ADCP6 (table 4). The Pearson correlation coefficients between depth-integrated computed SSC and air temperature at subseasonal time scales were negative at the two deepest sites, ADCP1 and ADCP5, and were not significant at the other sites. These correlation results indicate that there was more total suspended mass in the water column at the deepest sites when the air temperature was cooler and more total mass in the water column at three of the five sites when the current speeds were stronger. These relations are consistent with both increased resuspension as current speeds increase and increased sedimentation as air temperatures increase and are consistent with the correlations between vertical profiles of $R B$ and current speeds, and between vertical profiles of $R B$ and air temperatures.

Table 4. Correlation coefficients between the depth-integrated computed suspended solids concentrations (SSC) at ADCP sites and depth-integrated horizontal currents at the same site, or air temperature as measured at site WMR-MET, Upper Klamath Lake, south-central Oregon.

[Locations of sites are shown in figure 1. Time series were filtered to pass periods between 1.2 and 15 days. Correlation coefficients greater than 0.25 are significant and indicated by boldface type $(p<0.05)$. ADCP, acoustic Doppler current profiler]

\begin{tabular}{ccc}
\hline \multirow{2}{*}{ ADCP site } & \multicolumn{2}{c}{ Correlation of SSC with } \\
\cline { 2 - 3 } & $\begin{array}{c}\text { Currents } \\
\text { at ADCP site }\end{array}$ & $\begin{array}{c}\text { Air temperature at } \\
\text { site WMR-MET }\end{array}$ \\
\hline ADCP1 & $\mathbf{0 . 4 5}$ & $-\mathbf{0 . 3 3}$ \\
ADCP3 & -.17 & -.09 \\
ADCP5 & .52 & -.41 \\
ADCP6 & .34 & -.02 \\
ADCP7 & -.04 & .21 \\
\hline
\end{tabular}




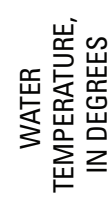
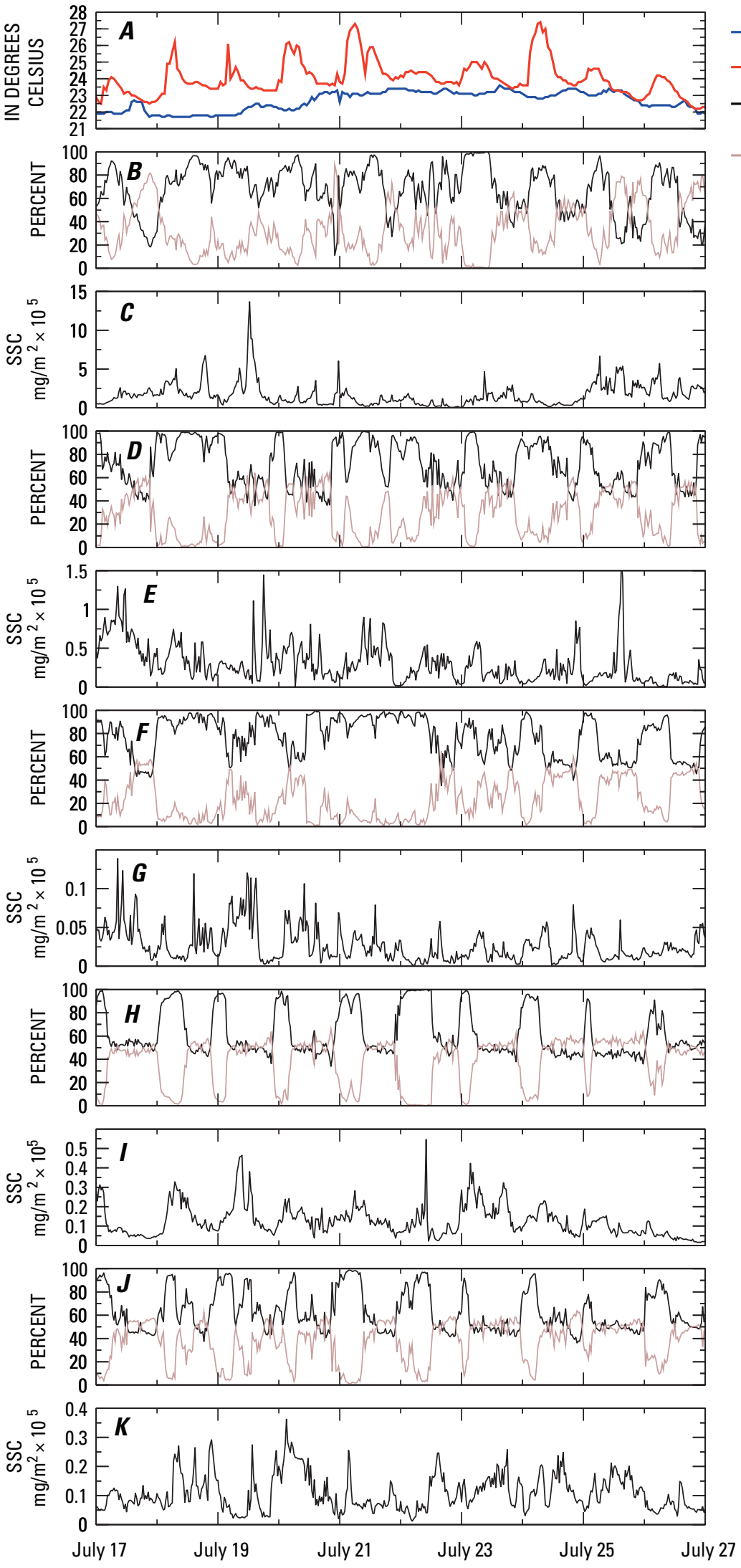

DATE IN 2005

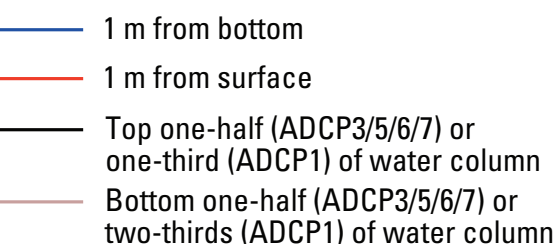

Figure 8. A: water temperature at site MDT, $1 \mathrm{~m}$ from surface, and $1 \mathrm{~m}$ from bottom; $B$ : Fraction of total water column mass contained in the upper one-third of the water column, fraction of total water column mass contained in the lower two-thirds of the water column at site ADCP1. $D, F, H$, J: Fraction of total water column mass contained in the upper one-half of the water column, fraction of total water column mass contained in the lower one-half of the water column, at sites ADCP3, $A D C P 5, A D C P 6$, and ADCP7, respectively. $C$, $E, G, I, K$ : Depth-integrated suspended solids at sites $A D C P 1, A D C P 3, A D C P 5, A D C P 6$, and $A D C P 7$, respectively. 

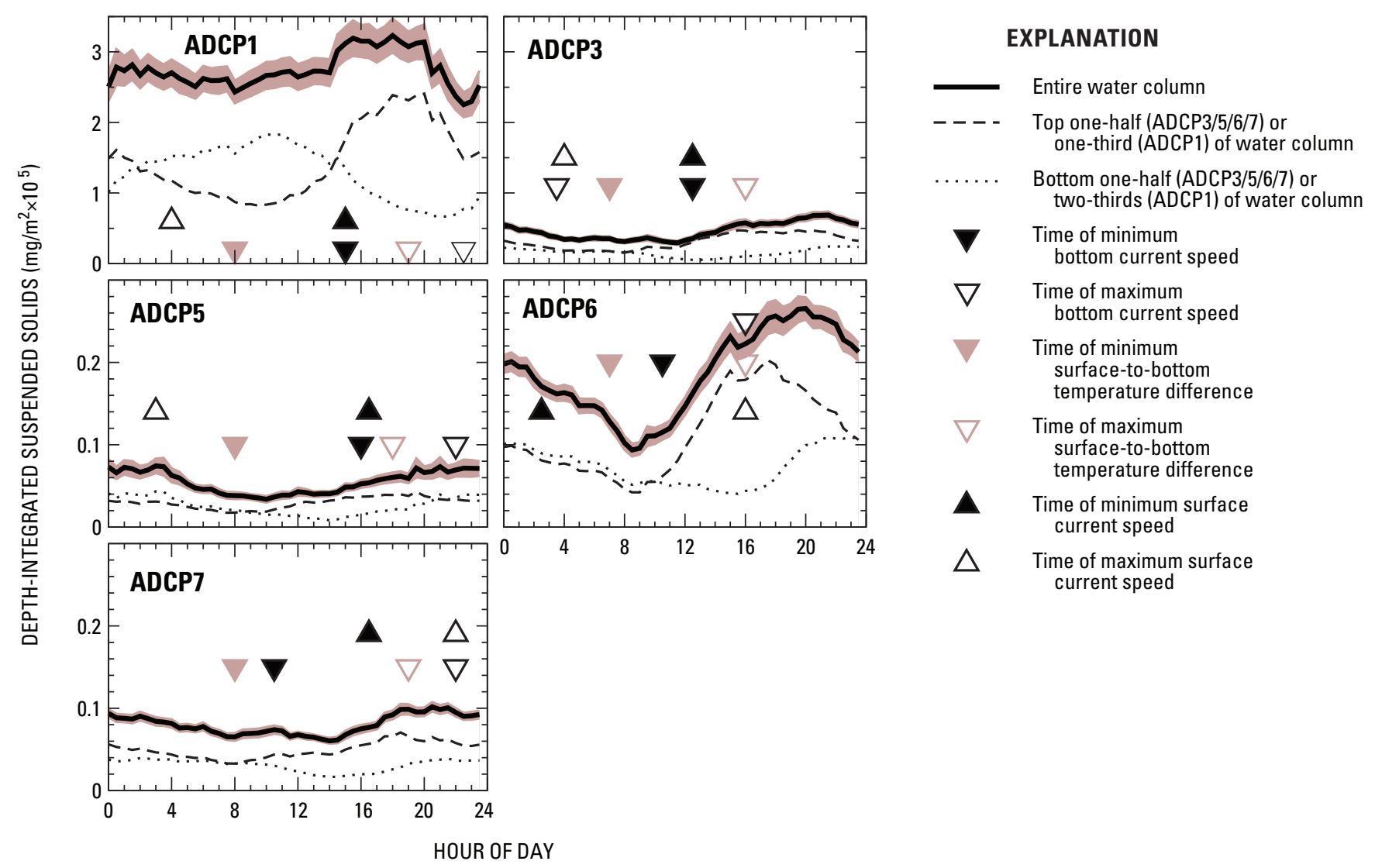

Figure 9. Seasonally averaged diel pattern of depth-integrated computed suspended solids concentration (SSC) in the entire water column and in the upper and lower one-half (upper one-third and lower two-thirds at ADCP1) of the water column. Time of maximum and minimum near-surface and near-bottom current speed and maximum and minimum surface-to-bottom temperature difference are shown for reference. Computed SSC are derived from an average of 30-minute values between June 21 and September 12, 2005. Shading indicates \pm 1 standard error around the estimate of mean SSC concentration.

\section{Discussion and Conclusions}

In order to draw conclusions regarding the behavior of cyanobacterial colonies in Upper Klamath Lake based on $R B$ and vertical velocities measured by ADCPs, one must be confident that the scatterers reflecting the acoustic signal back to the instruments are primarily cyanobacterial colonies. There is no way to differentiate among actively growing AFA, other organisms, and resuspended organic and inorganic material in $R B$ data. However, most of the suspended material collected from the ADCP sites in September 2006 was organic material: 62-95 percent at the shallow site and 48-85 percent at the deep site; the organic fractions near-surface generally were somewhat higher than organic fractions near-bottom (Gartner and others, 2007). The organic fraction comprises both phytoplankton and zooplankton. AFA completely dominates the phytoplankton species from June to October, reaching as much as $50 \mathrm{mg} / \mathrm{L}$ (wet weight) (Kann, 1998). The dominant zooplankton in the lake is Daphnia pulicaria; typical maximum seasonal concentrations are about 100 individuals per liter, and dry weights seldom exceed a few milligrams per liter (Kann, 1998). The D. pulicaria have the potential to affect the measured backscatter (and vertical velocity), especially because of their large size - the average length of the largest size class of $D$. pulicaria was $1.74 \mathrm{~mm}$ in 2005, and the average dry weight per individual was $20.75 \mu \mathrm{g} / \mathrm{animal}$ (A. St. Amand, Phycotech, unpub. data, 2005). The number of cyanobacterial colonies in the water column, however, typically is at least an order of magnitude higher than the number of $D$. pulicaria, suggesting that $D$. pulicari and other zooplankton contribute a minor component to the measured backscatter and vertical velocity. 
With regard to the inorganic fraction, resuspension of the bed material would be consistent with the observed positive and increasing correlation of $R B$ with horizontal currents with distance beneath the water surface at all measurement sites except site ADCP6. However, resuspended bed material in Upper Klamath Lake would be expected to be at least partially organic silt (Laenen and LeTourneau, 1996; Wood, 2001). Northwest winds greater than $4.5 \mathrm{~m} / \mathrm{s}$ are sufficient to resuspend bed sediment (Laenen and LeTourneau, 1996). Typical SSC values were calculated to be about $200 \mathrm{mg} / \mathrm{L}$ at low lake elevations of $4,137 \mathrm{ft}(1,260.96 \mathrm{~m}$, corresponding to a mean lake depth of $1.5 \mathrm{~m}$ ) but only about $5 \mathrm{mg} / \mathrm{L}$ at a lake elevation of 4,140 ft (1,261.87 m corresponding to a mean lake depth of $2.4 \mathrm{~m}$ ) (Laenen and LeTourneau, 1996). Lake elevations ranged from 4,143.1 to 4,139.5 ft (1,262.82 to $1,261.72 \mathrm{~m}$ ) during the 2005 ADCP deployments. (Lake elevations are from USGS water level gage 11507001.) Thus, with deeper lake levels, even with average diel winds exceeding $4.5 \mathrm{~m} / \mathrm{s}$ for several hours during late evening and early morning, typical values of resuspended material were expected to be low in 2005. In addition to predictions for relatively low levels of mobilized bed material, the measured $R B$ was usually less near-bottom than it was near-surface on both daily and seasonal time scales at each of the five ADCP sites. Although wind speeds were periodically high enough to resuspend bed materials and distribute mass throughout the water column, evidence of resuspended material should be evident with increased $R B$ measurements near-bottom. Correlations of $R B$ with current speeds were weaker than for $R B$ with wind or $R B$ with $\Delta T^{\circ}$; correlations were particularly poor at sites ADCP3 and ADCP6. In addition, the timing between $R B$ and wind and $R B$ and current speeds varied greatly among the five ADCP sites. If resuspended bed material were a substantial portion of the suspended material in the water column, it would be expected that the extrema of diel cycles of $R B$ generally would coincide with the extrema of diel cycles of near-bottom currents, which was not the case except at sites ADCP3 and ADCP5 where the extrema in $R B$ and near-bottom currents occurred within about an hour of each other. Mass was infrequently concentrated in the lower part of the water column, although it did happen occasionally, particularly at site ADCP1 where the current speeds were highest (fig. 9). Thus, the observations tended to support the hypothesis that the correlation of $R B$ with currents near- bottom was related more to mixing of suspended material downward from the surface than to resuspension of bed materials. Finally, the computed SSC was correlated with dissolved oxygen and chlorophyll $a$, other water quality indicators of bloom dynamics. It seems reasonable to conclude, therefore, that $R B$ is a useful surrogate for cyanobacterial mass (dominated by AFA) in Upper Klamath Lake although the presence of unknown, but generally small amounts of inorganic and organic sediments, detrital AFA particles, and zooplankton may decrease accuracy of results.
The theoretical model of light-driven vertical migration does not take into account the entrainment into turbulent eddies that occurs in wind-driven surface mixed layers (Reynolds, 2006). In Upper Klamath Lake, this mixed layer can extend to the bottom when winds are strong or to less than a meter from the surface when winds are light and the top-to-bottom temperature difference in the water column provides resistance to mixing. Because Upper Klamath Lake is shallow and mixes on an almost daily basis, it is likely that the vertical migration pattern of the colonies is controlled by the concurrent physical turbulence and thermal (density) characteristics of the water column as well as light availability.

The seasonally averaged diel cycles in measured $R B$, surface vertical velocity, and computed SSC provided insight into the behavior of AFA colonies on diel time scales. The diel pattern in $R B$ showed a maximum near the surface of the water column on a daily basis at all sites as the thermal stability of the water column increased in the afternoon, the result of a combination of rising colonies accumulating there and growth. The afternoon setup of thermal stability also resulted in a minimum in the measured $R B$ near the bottom at each site as floating colonies rose to the surface and sinking colonies settled out of the water column. A minimum in colonies near the surface and the most uniform distribution of colonies through the water column coincided with the period from late night to mid-morning associated with the minimum in temperature stratification (figs. 3 and $\underline{9}$ ).

Interpretation of the seasonally averaged diel cycle in vertical velocities was complicated by the fact that the measured velocity is an average of the motion of all suspended particles sampled by the ADCP acoustic beams, which may be a mix of positively, negatively, and neutrally buoyant particles. At the three shallowest sites, there was little evidence of any diel cycle in the surface vertical velocities, which generally were negative, and between -0.1 and $-0.2 \mathrm{~cm} / \mathrm{s}$, except at site ADCP3 where positive velocities as much as $0.1 \mathrm{~cm} / \mathrm{s}$ dominated the diel pattern. There were small diel fluctuations that were not consistent from site to site, but there was no indication of a daily switch between positively and negatively buoyant colonies consistent with light-driven migration. Only at the two deepest sites, ADCP1 and ADCP5, was there clear evidence of a diel cycle. At site ADCP5, that pattern was manifested as smaller sinking velocities in the afternoon; near-surface vertical velocity ranged from about $-0.4 \mathrm{~cm} / \mathrm{s}$ in the early morning to about $-0.15 \mathrm{~cm} / \mathrm{s}$ in the mid-afternoon. The diel cycle was strongest at site ADCP1, where the measured vertical velocity ranged from $-0.15 \mathrm{~cm} / \mathrm{s}$ in the early morning to $+0.15 \mathrm{~cm} / \mathrm{s}$ in the late afternoon. Both the floating and sinking velocities were large, implying that mass could be depleted or could accumulate at the surface in a matter of a few hours, which is supported by the highly dynamic diel cycles in surface $R B$. This is consistent with observations by Moreno-Ostos and others (2009), who concluded that diatom and AFA mass at the surface responded to changes in the wind stress within about 30 and 80 minutes, respectively. 
When $R B$ was converted to SSC, it was possible to calculate the movement of mass vertically through the water column. At all sites, based on the seasonally averaged diel cycle, mass was concentrated in the upper water column through the afternoon and evenly distributed between the upper and lower water column in the early morning hours, consistent with growth in the upper water column in the afternoon, and mixing of the water column in the early morning. As was the case with the $R B$ data, there was limited occurrence of mass concentration in the lower water column that would indicate potential resuspension of sediments. The depth-integrated mass at each site peaked in the late afternoon to early evening, usually a few hours later than the maximum in the upper water column. The difference between the daily minimum and maximum in depth-integrated mass at each site was large, ranging from 19 percent of the average at site ADCP1 to 92 percent of the average at site ADCP6. The highly dynamic nature of the diel cycle required large loss rates due to sedimentation and mortality within the water column, and large growth rates.

On subseasonal time scales, negative correlations of $R B$ and air temperature decreased from near-bottom upward and became positive at near-surface in the water column at most of the ADCP sites. Positive correlations of $R B$ and current speeds decreased from near-bottom upward and became negative near-surface at three ADCP sites. Because resuspended bed sediments were a minor component of suspended material, this correlation probably resulted primarily from a dispersal of colonies throughout the water column when the water column mixed more easily. The negative correlation near-surface at three ADCP sites indicated that colonies accumulated near-surface under conditions of increased water column stability. Moreno-Ostos and others (2009) observed the same relation between the vertical distribution of buoyant AFA and wind-induced mixing, and demonstrated that this behavior of positively buoyant colonies was easily distinguished from the behavior of negatively buoyant diatoms, which became depleted at the surface and accumulated in the lower water column when mixing was suppressed. At the two deepest sites, the surface vertical velocities were positively correlated with air temperature, consistent with decreased entrainment of floating colonies when air temperature increased. These correlations were consistent with increased concentration of AFA colonies near the surface when water column stability increased and dispersal of colonies throughout the water column when the water column mixed more easily. The depth-integrated mass at the two deepest sites was negatively correlated with air temperature and positively correlated with horizontal current speed. Thus, although the total water column SSC peaked with the highest air temperatures of the day on a daily basis, higher air temperatures were associated with lower total water column SSC on a subseasonal time scale. At site ADCP7, located at the mouth of Howard Bay, the correlations were inconsistent, but the maximum horizontal current speeds occurred near-bottom rather than near-surface or at mid-depth as they did at the other sites (Gartner and others, 2007; fig. 3). The near-surface currents and advection of suspended material were complicated by the movement of water across the entrance to Howard Bay at this site.

Successful application of a surrogate technology such as analysis of time series of measurements of $R B$ in conjunction with analysis of water samples has the potential to provide a less costly and labor intensive means of determining continuous and high resolution characteristics of the variable under study that is not otherwise possible. Analyses of both $R B$ and computed SSC, in conjunction with profiles of vertical velocity and an understanding of horizontal water current speeds measured by ADCPs in Upper Klamath Lake during 2005 contribute significant additional insights into seasonal, subseasonal, and diel patterns of AFA population dynamics in the lake.

\section{Acknowledgments}

The authors gratefully acknowledge the assistance of personnel from the USGS California Water Science Center, the USGS Oregon Water Science Center, and the USGS Klamath Falls Field Station who participated in various aspects of the fieldwork. Discussions with J. Rueter (Portland State University), J. Kann (Aquatic Ecosystem Sciences), and A. St. Amand (Phycotech) were very helpful. This work was partially funded by the U.S. Fish and Wildlife Service Hatfield Restoration Program (Interagency Agreement 814506H520) and the USGS National Research Program. Finally, the authors would like to thank several anonymous reviewers whose comments significantly aided in the preparation of this manuscript.

\section{References Cited}

\author{
Ashjian, C.J., Smith, S.L., Flagg, C.N., and Idrisi, Nasseer, \\ 2002, Distribution, annual cycle, and vertical migration \\ of acoustically derived biomass in the Arabian Sea during \\ 1994-1995: Deep Sea Research, Part II: Topical Studies in \\ Oceanography, v. 49, no. 12, p. 2377-2402. doi:10.1016/ \\ S0967-0645(02)00041-3, accessed November 23, 2010, at \\ http://www.ingentaconnect.com/content/els/09670645/2002 \\ 100000049/00000012/art00041.
}

American Society of Testing and Materials (ASTM), 1997, Standard test methods for determining sediment concentration in water samples: ASTM Standard D3977, ASTM International, West Conshohocken, PA, DOI: 10.1520/D3977-97. 
Deines, K.L., 1999, Backscatter estimation using broadband acoustic Doppler current profilers: Proceedings of the IEEE Sixth Working Conference on Current Measurement, San Diego, CA, March 11-13, 1999, p. 249-253.

Downing, A., Thorne, P.D., and Vincent, C.E., 1995, Backscattering from a suspension in the near field of a piston transducer: Journal of the Acoustical Society of America, v. 97, no. 3, p. 1614-1620.

Eilers, J.M., Kann, J., Cornett, J., Moser, K., and St. Amand, A., 2004, Paleolimnological evidence of change in a shallow, hypereutropic lake: Upper Klamath Lake, Oregon, USA: Hydrobiologia, v. 520, p. 7-18, doi:10.1023/ B:HYDR.0000027718.95901.ae, accessed November 23, 2010, at http://www.ingentaconnect.com/content $/ \mathrm{klu} /$ hydr/2004/00000520/F0030001/05264506.

Emery, W.J., and Thomson, R.E., 2001, Data analysis methods in physical oceanography, 2nd ed.: New York, Elsevier, $638 \mathrm{p}$.

Fishman, M.J., and Friedman, L.C., eds., 1989, Methods for determination of inorganic substances in water and fluvial sediments: U.S. Geological Survey Techniques of WaterResources Investigations, Book 5, Chap. A1, 545 p. (Also available at http://pubs.usgs.gov/twri/twri5-a1/.)

Flagg, C.N., and Smith, S.L., 1989, On the use of the acoustic Doppler current profiler to measure zooplankton abundance: Deep Sea Research, v. 36, no. 3, p. 455-474. doi:10.1016/0198-0149(89)900472, accessed November 23, 2010, at http://www. sciencedirect.com/science/article/B757K-48B0XDS-8X/2/ aa8eef10a9ce14e6a264ad2470369d69.

Gartner, J.W., 2004, Estimating suspended solids concentrations from backscatter intensity measured by acoustic Doppler current profiler in San Francisco Bay, California: Marine Geology, v. 211, Issues 3-4, p. 169-187, doi:10.1016/j.margeo.2004.07.001, accessed November 23, 2010, at http://www.sciencedirect.com/science/article/ B6V6M-4D9D9J9-1/2/7a9e130499e72ab8c1793b620e9ac 89f.

Gartner, J.W., Wellman, R.E., Wood, T.M., and Cheng, R.T., 2007, Water velocity and suspended solids measurements by in situ instruments in Upper Klamath Lake, Oregon: U.S. Geological Survey Open- File Report 2007-1279, 111 p. (Also available at http://pubs.usgs.gov/of/2007/1279/.)

Geiger, N.S., Gearheart, R., Henry, E., and Rueter, J., 2004, Preliminary research on Aphanizomenon flos-aquae at Upper Klamath Lake, Oregon: Report prepared for U.S. Fish and Wildlife Service, by Aquatic Scientific Resources, Portland, Oregon, 164 p.
Gray, J.R., and Gartner, J.W., 2009, Technological advances in suspended-sediment surrogate monitoring: Water Resources Research, v. 45, W00D29, 20 p., doi:10.1029/2008WR007063, accessed November 23, 2010, at http://www.agu.org/journals/ABS/2009/2008WR007063. shtml.

Heywood, K.J., 1996, Diel vertical migration of zooplankton in the Northeast Atlantic: Journal of Plankton Research, v. 18, no. 2, p. 163-184, doi:10.1093/plankt/18.2.163, accessed November 23, 2010, at http://plankt. oxfordjournals.org/content/18/2/163.full.pdf+html.

Heywood, K.J., Scrope-Howe, S., and Barton, E.D., 1991, Estimation of zooplankton abundance from shipborne ADCP backscatter: Deep Sea Research, v. 38, Issue 6, p. 677-691, doi:10.1016/0198-0149(91)90006-2, accessed November 23, 2010, at http://www.sciencedirect.com/ science/article/B757K-48BCJCK-2V/2/090b0dcceb3089f5f 3fe8dc93f1693f4.

Hoilman, G.R., Lindenberg, M.K., and Wood, T.M., 2008, Water quality conditions in Upper Klamath and Agency Lakes, Oregon, 2005: U.S. Geological Survey Scientific Investigations Report 2008-5026, 44 p. (Also available at http://pubs.usgs.gov/sir/2008/5026/.)

Holdaway, G.P., Thorne, P.D., Flatt, D., Jones, S.E., and Prandle, D., 1999, Comparison between ADCP and transmissometer measurements of suspended sediment concentration: Continental Shelf Research, v. 19, p. 421-441.

Huisman, J., Jonker, R.R., Zonneveld, C., and Weissing, F.J., 1999, Competition for light between phytoplankton species: Experimental tests of Mechanistic theory: Ecology, v. 80, no. 1, p. 211-222.

Kann, Jacob, 1998, Ecology and water quality dynamics of a shallow hypereutrophic lake dominated by cyanobacteria: University of North Carolina at Chapel Hill, PhD thesis.

Konopka, A., Kromkamp, J.C., and Mur, L.R., 1987, Regulation of gas vesicle content and buoyancy in light- or phosphate-limited cultures of Aphanizomenon flos-aquae (Cyanophyta): Journal of Phycology, v. 23, no. 1, p. 70-78.

Laenen, Antonius, and LeTourneau, A.P., 1996, Upper Klamath Basin nutrient-loading study - Estimate of windinduced resuspension of bed sediment during periods of low lake elevation: U.S. Geological Survey Open-File Report 95-414, 11 p., accessed November 23, 2010, at http:// or.water.usgs.gov/pubs_dir/Pdf/95-414.pdf.

Lindenberg, M.K., Hoilman, G.R., and Wood, T.M., 2008, Water quality conditions in Upper Klamath and Agency Lakes, Oregon, 2006: U.S. Geological Survey Scientific Investigations Report 2008-5201, 55 p. (Also available at http://pubs.usgs.gov/sir/2008/5201/.) 
Lohrmann, A., and Huhta, C., 1994, Plume measurement system (Plumes) calibration experiment, dredging Research program: Technical Report DRP-94-3, U.S. Army Corps of Engineers, Washington, D.C., 152 p.

Lorke, A., McGinnis, D.F., Spaak, P., and Wuest, A., 2004, Acoustic observations of zooplankton in lakes using Doppler current profiler: Freshwater Biology, v. 49, no. 10, p. 1280-1292.

Moreno-Ostos, E., Cruz-Pizarro, L., Basanta, A., and George, D.G., 2009, The influence of wind-induced mixing on the vertical distribution of buoyant and sinking phytoplankton species: Aquatic Ecology, v. 43, p. 271-284.

Pinot, J.M., and Jansa, J., 2001, Time variability of acoustic backscatter from zooplankton in the Ibiza Channel (western Mediterranean): Deep Sea Research, Part I: Oceanographic Research, v. 48, no. 7, p. 1651-1670.

Plueddemann, A.J., and Pinkel, Robert, 1989, Characterization of the patterns of diel migration using a Doppler sonar: Deep Sea Research, v. 36, no. 4, p. 509-530.

Porat, R., Teltsch, B., Perelman, A., and Dubinsky, Z., 2001, Diel buoyancy changes by the cyanobacterium Aphanizomenon ovalisporum from a shallow reservoir: Journal of Plankton Research, v. 23, no. 7, p. 753-763, doi: 10.1093/plankt/23.7.753, accessed November 23, 2010, at http://plankt.oxfordjournals.org/content/23/7/753.full.

Reynolds, C.S., 2006, The Ecology of Phytoplankton: Cambridge University Press, 535 p.

Schott, F., and Johns, W., 1987, Half-year-long measurements with a buoy-mounted acoustic Doppler current profiler in the Somali Current: Journal of Geophysical Research, v. 92, no. C5, p. 5169-5176.

Schulkin, M., and Marsh, H.W., 1962, Sound absorption in sea water: Journal of the Acoustical Society of America, v. 34, no. 6, p. 864-865.

Sutor, M.M., Cowles, T.J., Peterson, W.T., and Pierce, S.D., 2005, Acoustic observations of finescale zooplankton distributions in the Oregon upwelling region: Deep Sea Research, Part II: Topical Studies in Oceanography, v. 52, Issues 1-2, p. 109-121, doi:10.1016/j.dsr2.2004.09.029, accessed November 23, 2010, at http://www. sciencedirect.com/science/article/B6VGC-4FBFPY2-1/2/ adad0e1fd71062b0fa282c43084ff56c.

Thevenot, M.M., Prickett, T.L., and Kraus, N.C., 1992, Tylers Beach, Virginia, dredged material plume monitoring project 27 September to 4 October 1991: Dredging Research Program Technical Report DRP-92-7, U.S. Army Corps of Engineers, Washington, D.C., 204 p.
Thevenot, M.M., and Kraus, N.C., 1993, Comparison of acoustical and optical measurements of suspended material in the Chesapeake Estuary: Journal of Marine Environmental Engineering, v. 1, Gordon and Breach Science Publishers, p. 65-79.

Thorne, P.D., Vincent, C.E., Hardcastle, P.J., Rehman, S., and Pearson, N., 1991, Measuring suspended sediment concentrations using acoustic backscatter devices: Marine Geology, v. 98, Issue 1, p. 7-16. doi:10.1016/00253227(91)90031-X, accessed November 23, 2010, at http:// www.sciencedirect.com/science/article/B6V6M-489S3VN1B/2/6349386e124a1f96ded6bc53041e4d96.

Topping, D.J., Wright, S.A., Melis, T.S., and Rubin, D.M., 2007, High-resolution measurements of suspendedsediment concentration and grain size in the Colorado River in Grand Canyon using a multi-frequency acoustic system: Proceedings of the 10th International Symposium on River Sedimentation, Moscow, Russia, v. 3, p. 330-339.

Urick, R.J., 1975, Principles of underwater sound, 2nd ed.: New York, McGraw Hill, 384 p.

Wall, G.R., Nystrom, E.A., and Litten, S., 2006, Use of an ADCP to compute suspended-sediment discharge in the tidal Hudson River, New York: U.S. Geological Survey Scientific Investigations Report 2006-5055, 16 p. (Also available at http://pubs.usgs.gov/sir/2006/5055/.)

Wood, T.M., 2001, Sediment oxygen demand in Upper Klamath and Agency Lakes, Oregon, 1999: U.S. Geological Survey Water-Resources Investigations Report 01-4080, 13 p. (Also available at http://or.water.usgs.gov/pubs_dir/ WRIR01-4080/.)

Wood, T.M., Hoilman, G.R., and Lindenberg, M.K., 2006, Water-quality conditions in Upper Klamath Lake, Oregon, 2002-04: U.S. Geological Survey Scientific Investigations Report 2006-5209, 54 p. (Also available at http://pubs.usgs. gov/sir/2006/5209/.)

Wood, T.M., Cheng, R.T., Gartner, J.W., Hoilman, G.R., Lindenberg, M.K., and Wellman, R.E., 2008, Modeling hydrodynamics and heat transport in Upper Klamath Lake, Oregon, and implications for water quality: U.S. Geological Survey Scientific Investigations Report 2008-5076, 48 p. (Also available at http://pubs.usgs.gov/sir/2008/5076/.)

Zhou, Meng, Nordhausen, Walter, and Huntley, Mark, 1994, ADCP measurements of the distribution and abundance of euphausiids near the Antarctic Peninsula in winter: Deep Sea Research Part I: Oceanographic Research Papers, 41, no. 9, p. 1425-1445, doi:10.1016/0967-0637(94)90106-6, accessed November 23, 2010, at http://www.sciencedirect. com/science/article/B6VGB-48B0776-T/2/732a42190db47a 2147afe590018767d3. 
Publishing support provided by the U.S. Geological Survey

Publishing Network, Tacoma Publishing Service Center

For more information concerning the research in this report, contact the Director, Oregon Water Science Center

U.S. Geological Survey

2130 SW 5th Avenue

Portland, Oregon 97201

http://or.water.usgs.gov 


\section{总}

용

ํㅡㅁ

9

产

จ

茓

률

疍

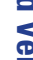

공

政

옹



$\frac{d}{\pi}$

응 